\title{
Analyses of protein corona on bare and silica-coated gold nanorods against four mammalian cells
}

This article was published in the following Dove Press journal:

International Journal of Nanomedicine

20 February 2015

Number of times this article has been viewed

\author{
Minakshi Das' \\ Dong Kee $\mathrm{Yi}^{2}$ \\ Seong Soo A An' \\ 'Department of Bionanotechnology, \\ Gachon University, Seongnam, \\ Republic of Korea; ${ }^{2}$ Department of \\ Chemistry, Myongji University, Yongin, \\ Republic of Korea
}

\begin{abstract}
The purpose of this study was to investigate the mechanisms responsible for the toxic effects of gold nanorods (AuNRs). Here, a comprehensive study was performed by examining the effects of bare (uncoated) AuNRs and AuNRs functionalized with silica ( $\mathrm{SiO}_{2}$-AuNRs) against various mammalian cell lines, including cervical cancer cells, fibroblast cells, human umbilical vein endothelial cells, and neuroblastoma cells. The interactions between AuNRs and mammalian cells were investigated with cell viability and mortality assays. Dihydrorhodamine-123 assay was carried out for evaluating reactive oxygen species (ROS) generation, along with mass spectroscopy analysis for determining the composition of the protein corona. Our results suggest that even the lowest concentrations of AuNRs $(0.7 \mu \mathrm{g} / \mathrm{mL})$ induced ROS production leading to cell mortality. On the other hand, cellular viability and ROS production were maintained even at a higher concentration of $\mathrm{SiO}_{2}$-coated AuNRs $(12 \mu \mathrm{g} / \mathrm{mL})$. The increased production of ROS by AuNRs seemed to cause the toxicity observed in all four mammalian cell types. The protein corona on the bare AuNRs did not appear to reduce ROS generation; however, different compositions of the protein corona on bare and $\mathrm{SiO}_{2}$-coated AuNRs may affect cellular behavior differently. Therefore, it was determined that $\mathrm{SiO}_{2}$-coated AuNRs would be more advantageous than bare AuNRs for cellular applications.
\end{abstract}

Keywords: gold nanorods, silica coating, oxidative stress, mammalian cells, cell toxicity, protein corona

\section{Introduction}

Nanoparticles are comparable in size with many organic entities and subcellular compounds; thus, nanoparticles may interact with a range of biological systems, depending on composition and specific application. Such interactions may be helpful for treating various diseases; however, the use of these nanoparticles could also have adverse effects leading to toxicity and cellular death. Numerous studies have described the interactions of gold nanorods (AuNRs) with various mammalian cells. ${ }^{1-3}$ AuNRs have been described as not entering the nucleus but remaining entrapped in the vesicles. However, the exact pathway for AuNRs is not known. In general, larger particles move through cells via phagocytosis, whereas receptor-mediated endocytosis is considered the most important working mechanism. ${ }^{4}$

While it is essential to understand the potential benefits of AuNRs on cellular behavior, it is equally important to address any toxicity concerns. Thus, another key challenge is determining the exact mechanism responsible for cellular toxicity. Several biochemical tests have been applied to determine the levels of nanomaterials that were toxic to cell lines, using viability, reactive oxygen species (ROS), and 
genotoxicity assays. ${ }^{5}$ Two major components were deemed to be responsible for the toxic effects of AuNRs covered with surface ligands, which were identified as cetyltrimethylammonium bromide (CTAB) bilayers and residual or desorbed reagent-free CTAB molecules. This surfactant was shown to be poisonous to cells, even at low concentrations. ${ }^{1}$ In addition, ROS formation and cellular oxidative stress were proposed as possible mechanisms for nanoparticle toxicity. ${ }^{6-8}$ It was reported that oxidative stress by nanoparticles was correlated with increased ROS. ${ }^{9}$ Furthermore, the interaction of nanomaterials with the biological fluids creating protein layers on the surface of the nanomaterials, termed the "protein corona", has garnered much attention. Therefore, in the present study, we investigated the interaction of nanomaterials and mammalian cells to determine the cytotoxicity mechanism induced by AuNRs and AuNRs functionalized with a silica coating $\left(\mathrm{SiO}_{2}\right.$-AuNRs) in four different cell lines: cervical cancer cells (HeLa), fibroblast cells (FY-11), human umbilical vein endothelial cells (HUVECs), and neuroblastoma cells (SH-SY5Y). Cytotoxicity was analyzed using several cell viability assays, including the 3-(4,5-dimethyl2-thiazolyl)-2,5-diphenyltetrazolium bromide (MTT) assay and a CellTiter-Glo ${ }^{\circledR}$ assay. For this evaluation, we focused on the oxidative effects induced by nanomaterials, which resulted in decreased cellular viability and increased cellular death. In addition, mass spectroscopy (MS) analysis indicated involvement of the protein corona layer formed on the AuNRs and $\mathrm{SiO}_{2}-\mathrm{AuNRs}$ in inducing free-radical production inside the cells.

\section{Materials and methods Materials}

Gold (III)chloride trihydrate $\left(\mathrm{HAuCl}_{4}\right)$, sodium borohydride $\left(\mathrm{NaBH}_{4}\right), \mathrm{CTAB}$, ascorbic acid (AA), and silver nitrate $\left(\mathrm{AgNO}_{3}\right)$ were purchased from Sigma-Aldrich (St Louis, MO, USA). 3-Mercaptopropyltrimethoxy silane (MPS) and ammonium hydroxide $\left(\mathrm{NH}_{4} \mathrm{OH}\right)$ were purchased from Aldrich (Milwaukee, WI, USA). Ultrapure deionized water was used for preparing all solutions and subsequent experiments.

Phosphate-buffered saline (PBS, pH 7.4), MTT assay reagent, and dihydrorhodamine-123 (DHR) were purchased from Sigma-Aldrich. Dulbecco's Modified Eagle's Medium (DMEM) and DMEM/F12 were purchased from Gibco-Invitrogen (Grand Island, NY, USA). Endothelial Cell Basal Medium-2 (EBM-2) was purchased from Lonza (Walkersville, MD, USA). Heat-inactivated fetal bovine serum (FBS), penicillin and streptomycin, and other tissue culture reagents were purchased from Thermo Scientific (Waltham, MA, USA). The CellTiter-Glo ${ }^{\circledR}$ assay kit was purchased from Promega (Madison, WI, USA).

\section{Synthesis of AuNRs}

AuNRs were synthesized according to previously described methods. ${ }^{10}$ Briefly, $0.25 \mathrm{~mL}$ of aqueous $0.01 \mathrm{M}$ $\mathrm{HAuCl}_{4} \cdot 3 \mathrm{H}_{2} \mathrm{O}$ solution and $7.5 \mathrm{~mL}$ of $0.10 \mathrm{M}$ CTAB were mixed in a conical flask, after which $0.6 \mathrm{~mL}$ of $0.01 \mathrm{M}$ ice-cold $\mathrm{NaBH}_{4}$ solution was added to the flask. Following the addition of $\mathrm{NaBH}_{4}$, the clear white solution turned to a brick-brown color, indicating the formation of Au nanoparticles. This solution was aged for 2.5 hours at $25^{\circ} \mathrm{C}-28^{\circ} \mathrm{C}$ to form the seed solution.

Meanwhile, in another beaker, $9.5 \mathrm{~mL}$ of $0.1 \mathrm{M} \mathrm{CTAB}$, $0.4 \mathrm{~mL}$ of $0.01 \mathrm{M} \mathrm{HAuCl}_{4} \cdot 3 \mathrm{H}_{2} \mathrm{O}$, and $0.03 \mathrm{~mL}$ of $0.01 \mathrm{M}$ $\mathrm{AgNO}_{3}$ were mixed. A volume of $0.064 \mathrm{~mL}$ of $0.1 \mathrm{M}$ ascorbic acid was added to the mixture, which immediately turned the solution from orange-yellow to colorless. Finally, $0.010 \mathrm{~mL}$ of the seed solution was added, the solution was gently mixed for 10 seconds, and then it was left undisturbed for 24 hours.

\section{Synthesis of $\mathrm{SiO}_{2}-\mathrm{AuNRs}$}

$\mathrm{SiO}_{2}$-AuNRs were synthesized according to a previously published method. ${ }^{11-14}$ A volume of $3 \mathrm{~mL}$ of the AuNRs solution was centrifuged to remove excess CTAB and was redispersed in distilled water. A solution containing $5.58 \mu \mathrm{L}$ of MPS in $20 \mathrm{~mL}$ of ethanol was prepared, and $80 \mu \mathrm{L}$ of the solution was added to the AuNRs solution under vigorous magnetic stirring for 30 minutes to achieve a silica coating of intermediate thickness (around $3 \mathrm{~nm}$ ). A volume of $20 \mu \mathrm{L}$ of $\mathrm{NH}_{4} \mathrm{OH}$ ( $\mathrm{pH}$ 9) was then added, and the solution was vigorously stirred for 1 hour. The solution was washed three times with ethanol by centrifugation and was treated with $70 \%$ ethanol to eliminate any bacteria. A schematic representation of the AuNRs and $\mathrm{SiO}_{2}$-AuNR synthesis process is shown in Figure 1.

\section{Characterizations}

Transmission electron microscopy (TEM) was performed using a JEM-3010 microscope (JEOL, Tokyo, Japan) operating at $300 \mathrm{kV}$. TEM samples were prepared by depositing $10 \mu \mathrm{L}$ of the $\mathrm{SiO}_{2}$-AuNRs suspension on carboncoated copper grids, which was followed by the removal of excess solution and vacuum drying in an oven for 24 hours. Ultraviolet-visible (UV-Vis) spectra of the $\mathrm{SiO}_{2}$-AuNRs were measured using an Optizen 2120 UV spectrophotometer 

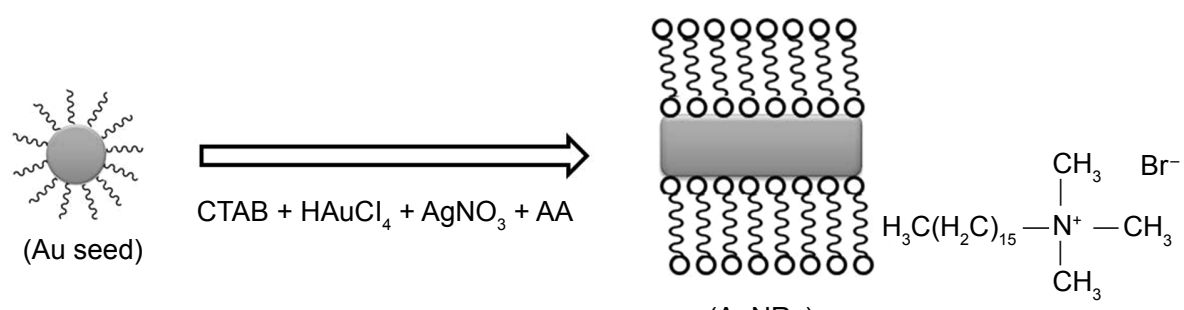

(AuNRs)
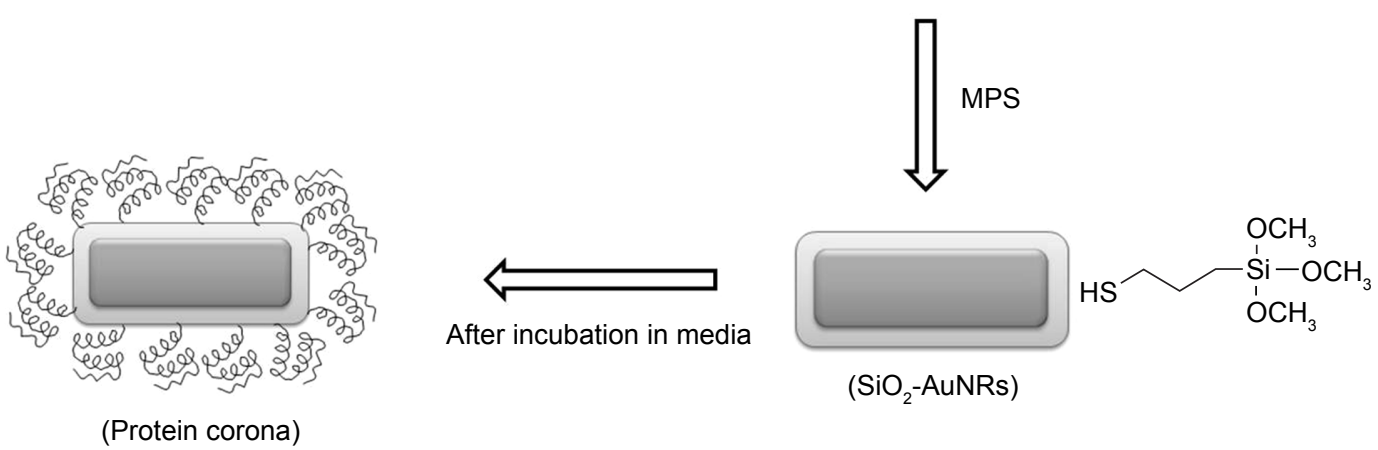

$\left(\mathrm{SiO}_{2}-\mathrm{AuNRs}\right)$

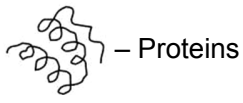

Figure I Schematic representation of $\mathrm{AuNRs}$ and $\mathrm{SiO}_{2}-\mathrm{AuNRs}$ synthesis along with protein corona formation.

Abbreviations: CTAB, cetyltrimethylammonium bromide; AA, ascorbic acid; AuNRs, gold nanorods; MPS, mercaptopropyltrimethoxy silane; SiO ${ }_{2}$-AuNRs, gold nanorods functionalized with silica.

(Mecasys, Daejeon, Korea) from $400 \mathrm{~nm}$ to 1,000 $\mathrm{nm}$ in $1 \mathrm{~cm}$ cuvettes. Zeta potential measurements were conducted using a Zetasizer Nano ZS system (Malvern Instruments, Malvern, UK).

\section{Cell culture and treatment with AuNRs/ $\mathrm{SiO}_{2}$-AuNRs}

FY-11 cells were cultured in DMEM containing 10\% (v/v) FBS and $1 \%(\mathrm{w} / \mathrm{v})$ penicillin/streptomycin at $37^{\circ} \mathrm{C}$ in a humidified atmosphere of $5 \% \mathrm{CO}_{2}$ for 24 hours. Then, cells were seeded at a density of $2 \times 10^{4}$ cells/well in flat-bottom 96-well plates (SPL Life Sciences, Seoul, Korea) and maintained at the same temperature and atmospheric conditions for up to 24 hours to allow cells to attach to the bottom of the plate. The cells were then washed with PBS and treated with AuNRs and $\mathrm{SiO}_{2}$-AuNRs in a serum-free medium at concentrations ranging from $0.7 \mu \mathrm{g} / \mathrm{mL}$ to $12 \mu \mathrm{g} / \mathrm{mL}$ for 24 hours. After 24 hours, the medium was removed and the cells were washed twice with PBS to remove excess NRs. Cells cultured with NR-free medium served as control samples.

\section{Cell viability analysis using MTT assay}

The effect of AuNRs and $\mathrm{SiO}_{2}$-AuNRs on FY-11 cell viability was evaluated using an MTT colorimetric assay, as described in previous studies. ${ }^{15}$ MTT solution (approximately $0.5 \mathrm{mg} / \mathrm{mL}$ ) was added to wells containing fresh medium and previously cultured cells. The cultures were incubated at $37^{\circ} \mathrm{C}$ for 2 hours. Formazan crystals were then dissolved in dimethyl sulfoxide by discarding the medium. UV absorbance was measured using a microplate reader, and the data were interpreted as the percentage of viable cells relative to the control. The same procedure was repeated for HeLa cells, but for the SH-SY5Y and HUVEC cells, DMEM/F12 and EBM-2 medium, respectively, was used for culturing the cells.

\section{CellTiter-Glo ${ }^{\circledR}$ assay of cell viability}

The CellTiter-Glo ${ }^{\circledR}$ assay was performed according to the manufacturer's protocol. The previously described culture procedures were repeated for the HeLa cells. DMEM/F12 and EBM-2 medium was used for culturing the SH-SY5Y and HUVEC cells, respectively.

\section{Cell mortality assay}

Cell mortality was assessed as previously described ${ }^{6}$ using a Trypan blue assay (Sigma). The FY-11 cells were plated in 12-well plates, with each well containing $2 \times 10^{4}$ cells/ well. The cells were treated with various concentrations of AuNRs and $\mathrm{SiO}_{2}$-AuNRs $(0.7,1.5,3,6$, and $12 \mu \mathrm{g} / \mathrm{mL})$ that were added to the culture medium. Cells cultured in 
nanoparticle-free medium were used as the control. After 24 hours, the supernatant was collected, and the cells were detached with $300 \mu \mathrm{L}$ of trypsin-ethylenediaminetetraacetic acid solution. The mixture, consisting of the supernatant and detached cells, was centrifuged at 1,200 rpm for 5 minutes. The obtained pellet was then dispersed in $500 \mu \mathrm{L}$ of Trypan blue. After staining for 5 minutes, the cells were counted using a Countess Automated Cell Counter (Invitrogen, Grand Island, NY, USA). Cell mortality (\%) was expressed in terms of dead cell number/total cell number. This procedure was repeated for the HeLa, SH-SY5Y, and HUVEC cell lines.

\section{Measurement of intracellular ROS}

ROS generation was determined using DHR-123, as described previously. ${ }^{7}$ Cells were plated into 96-well plates. After 24 hours of incubation, the medium was discarded, and the cells were preincubated with $100 \mu \mathrm{L}$ of $10 \mu \mathrm{M}$ DHR-123 solution and the growth medium at $5 \% \mathrm{CO}_{2}, 95 \%$ air at $37^{\circ} \mathrm{C}$ for 30 minutes. Following the incubation period, the medium was removed and cells were washed three times with PBS. The cells were then exposed to AuNRs and $\mathrm{SiO}_{2}$-AuNRs at concentrations of $0.75,1.5,3,6$, and $12 \mu \mathrm{g} / \mathrm{mL}$ for 24 hours. The fluorescence intensity of each well was analyzed using a microplate reader (Victor 3; Perkin-Elmer, Waltham, MA, USA) with an excitation filter of $485 \mathrm{~nm}$ and an emission filter of $535 \mathrm{~nm}$. This procedure was repeated for the HeLa, SH-SY5Y, and HUVEC cell lines.

\section{Identification of the protein corona using MS}

AuNRs and $\mathrm{SiO}_{2}$-AuNRs were incubated in DMEM and Roswell Park Memorial Institute (RPMI) medium for 1 hour at $37^{\circ} \mathrm{C}$ with rotation. After 1 hour, the samples were centrifuged at $18,000 \times g$ for 30 minutes, and the supernatant was discarded. PBS was then added to resuspend the AuNRs and
$\mathrm{SiO}_{2}$-AuNRs. This washing procedure was repeated three times, and the samples were then sent for MS determination at Diatech (Korea) to confirm the formation of the protein corona.

\section{Statistical analysis}

Statistical analysis performed was based on three replicates of each experiment. The significant differences were examined using Student's $t$-test. Significance was analyzed at $P<0.05$.

\section{Results \\ Characterization of AuNRs and $\mathrm{SiO}_{2}-$ AuNRs}

The CTAB-stabilized AuNRs were encapsulated with a CTAB bilayer on their surface. For typical $\mathrm{SiO}_{2}$-AuNRs synthesis, removal of the unbound CTAB is essential; therefore, the washing step must be performed very carefully. Here, with the use of a silane-coupling agent, uniform layers of $\mathrm{SiO}_{2}$ were formed, with an aspect ratio of 3.0 0 0.2. A uniform silica coating over AuNRs can be seen in Figure 2.

\section{Characterization UV-Vis spectra}

The UV-Vis spectra of the AuNRs before and after coating with $\mathrm{SiO}_{2}$ showed that the physiochemical properties of the AuNRs are altered (Figure 3). The prepared AuNRs have a weak transverse plasmon band at $522 \mathrm{~nm}$ and a strong longitudinal plasmon band at $630 \mathrm{~nm}$, whereas for the $\mathrm{SiO}_{2}$-AuNRs, the longitudinal surface plasmon band was red-shifted by $5 \mathrm{~nm}$. This shift is attributed to an increase in the local refractive index of the medium surrounding the AuNRs after the formation of $\mathrm{SiO}_{2}$ shell.

\section{Characterization of zeta potential}

The AuNR surface is positively charged due to the presence of polycations; thus, the zeta potential value was observed to be
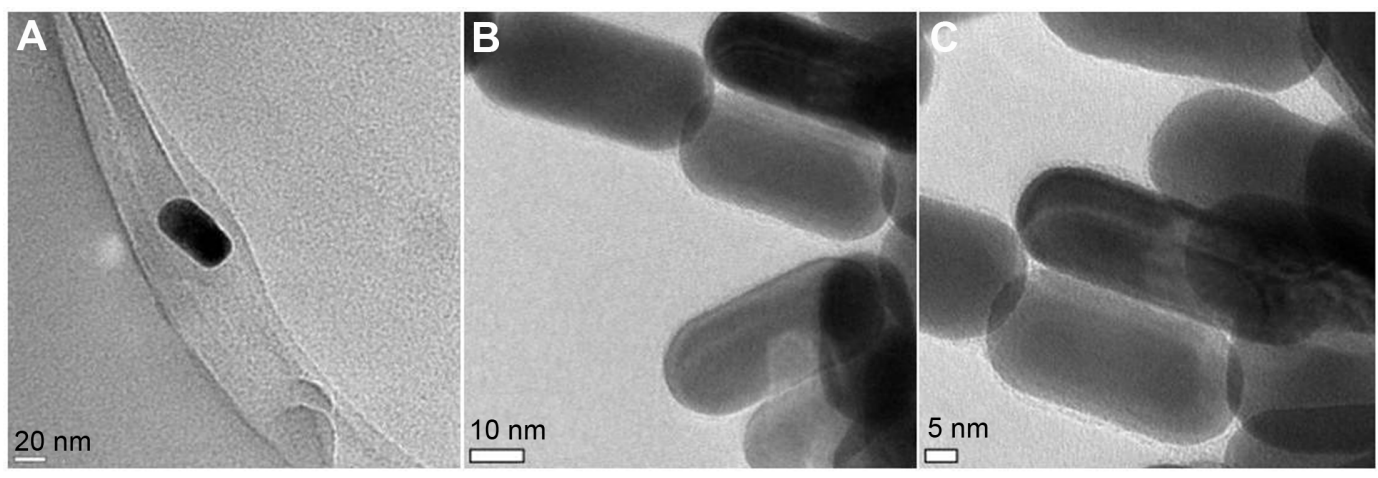

Figure 2 Transmission electron microscope images of AuNRs $(\mathbf{A})$ and intermediate $\mathrm{SiO}_{2}$-AuNRs, showing a silica shell thickness of around 3 nm (B and C). 


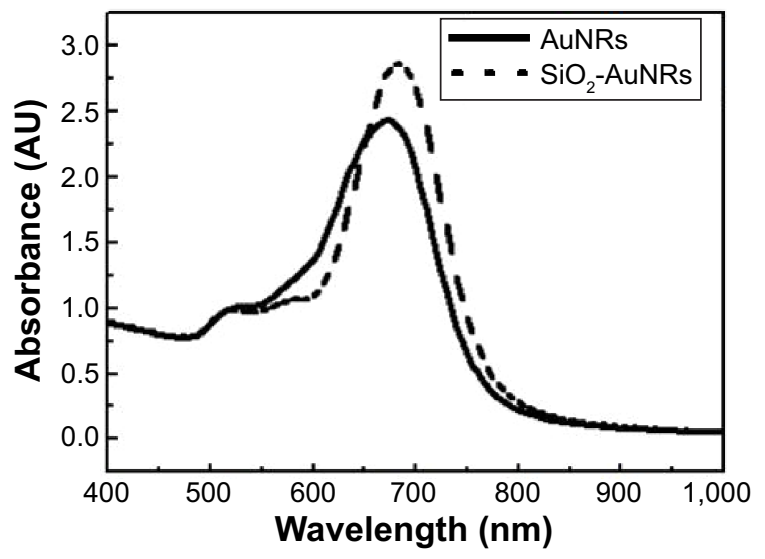

Figure 3 UV-Vis spectra of AuNRs and $\mathrm{SiO}_{2}$-AuNRs.

Note: AuNRs show a weak transverse plasmon band at $522 \mathrm{~nm}$ and a strong longitudinal plasmon band at $630 \mathrm{~nm}$, whereas for the $\mathrm{SiO}_{2}$-AuNRs, the longitudinal surface plasmon band was red shifted by $5 \mathrm{~nm}$.

Abbreviations: AuNRs, gold nanorods; $\mathrm{SiO}_{2}-\mathrm{AuNRs}$, gold nanorods functionalized with silica; UV-Vis, ultraviolet-visible spectroscopy.

$66.2 \mathrm{mV}$, whereas after coating with $\mathrm{SiO}_{2}$, the surface becomes negatively charged with a value of $-25.7 \mathrm{mV}$, as shown in Figure 4A and B. These zeta potential values confirm the stability and decreased aggregation of the AuNRs and $\mathrm{SiO}_{2}-$ AuNRs, and therefore the zeta potential results confirm the coating of the AuNR surfaces with $\mathrm{SiO}_{2}$.

\section{Cellular viability based on the CellTiter-Glo ${ }^{\circledR}$ assay}

The mitochondrial function and cellular viability of the HeLa, FY-11, SH-SY5Y, and HUVEC cells, in the presence of AuNRs and $\mathrm{SiO}_{2}$-AuNRs, are shown in Figure 5A-D. AuNRs induced toxicity even at the lowest concentration, whereas $\mathrm{SiO}_{2}$-AuNRs maintained more than $80 \%$ of cellular viability for all concentrations. Similar viability was observed in the case of all four cell types.

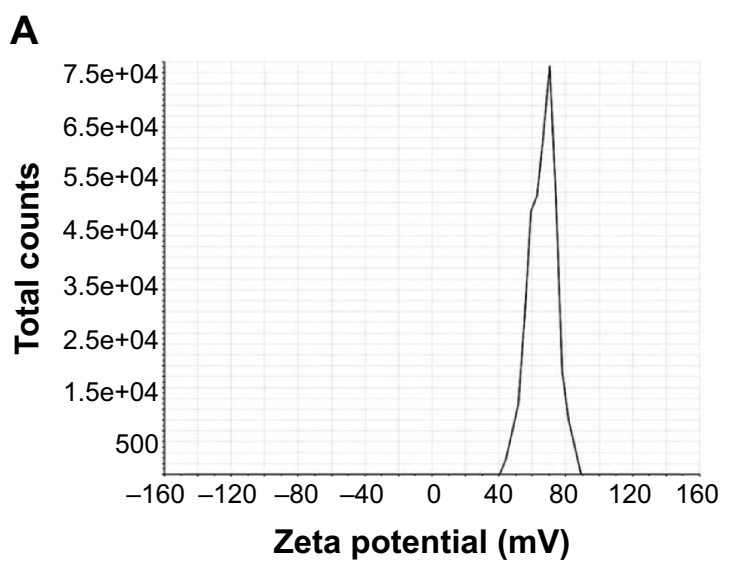

\section{Cellular viability based on MTT assay}

The cytotoxicity of AuNRs incubated with the cells was shown to be quite high, decreasing metabolic activity by about $50 \%$, whereas even at high $\mathrm{SiO}_{2}-\mathrm{AuNR}$ concentrations, $80 \%$ viability was maintained, as shown in Figure $6 \mathrm{~A}-\mathrm{D}$. As shown in Figure 6, the toxic effect of the AuNRs on mitochondrial activity increased with increasing concentrations.

\section{Cellular mortality}

In this study, cellular mortality was monitored using the Trypan blue assay, where dead cells were stained blue, while live cells remained unchanged. Mortality was expressed as the ratio of dead cells to total cells. Here, greater cell mortality (\%) was observed in the presence of AuNRs, whereas cellular mortality was relatively low with the $\mathrm{SiO}_{2}$-AuNRs. As shown in Figure 7, the HeLa, FY-11, SH-SY5Y, and HUVEC cells had an average mortality percentage of around $0.4 \%$, even at the highest concentration of $12 \mu \mathrm{g} / \mathrm{mL} \mathrm{SiO}_{2}-$ AuNRs, whereas mortality even at lower concentrations of AuNRs was quite high at around $0.3 \%$ for all cells. For the $\mathrm{SiO}_{2}$-AuNRs, cellular mortality remained almost similar to the control for all cells, while the AuNRs exhibited relatively high cell mortality.

\section{NR-induced ROS generation}

The formation of intracellular free-radical levels could induce oxidative damage to cellular components, ultimately resulting in necrosis. The potential of AuNRs and $\mathrm{SiO}_{2}$-AuNRs to induce oxidative stress was determined by measuring the ROS levels. Significant ROS elevation was observed for the HeLa, FY-11, SH-SY5Y, and HUVEC cells after 24 hours of exposure to the AuNRs and $\mathrm{SiO}_{2}$-AuNRs at concentrations including $0.7,1.5,3,6$, and $12 \mu \mathrm{g} / \mathrm{mL}$.

\section{B}

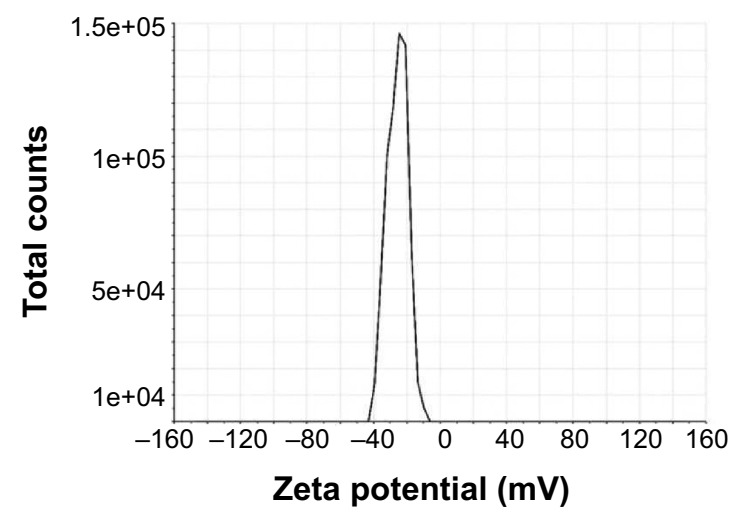

Figure 4 Surface charge analysis of nanorods by zeta potential measurement.

Note: (A) AuNRs possessed high positive surface charge with a value of $66.2 \mathrm{mV}$ and (B) $\mathrm{SiO}_{2}$-AuNRs possessed negative surface charge with a value $-25.7 \mathrm{mV}$. Abbreviations: AuNRs, gold nanorods; $\mathrm{SiO}_{2}-\mathrm{AuNRs}$, gold nanorods functionalized with silica. 
A

- AuNRs $\square \mathrm{SiO}_{2}$-AuNRs

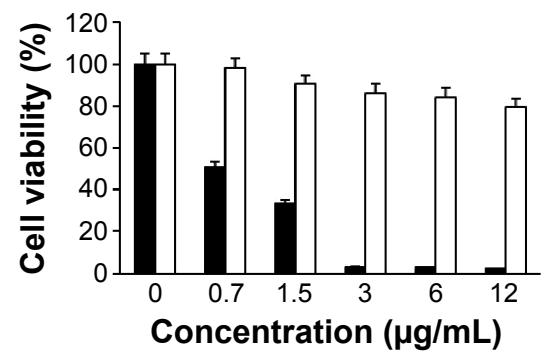

C

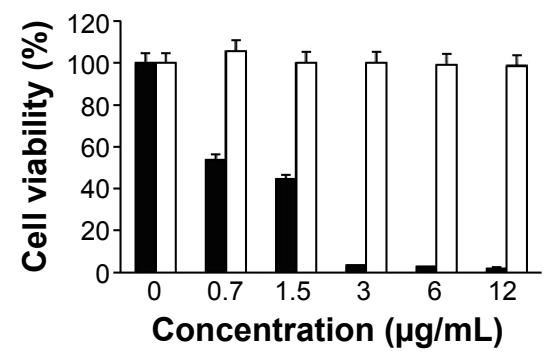

B

- AuNRs $\square \mathrm{SiO}_{2}$-AuNRs

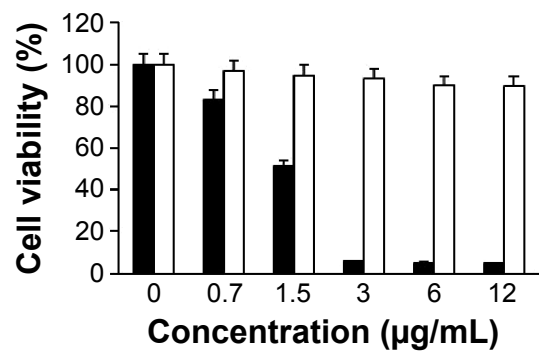

D

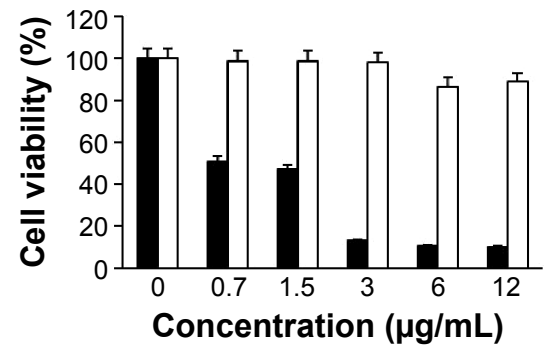

Figure 5 Shows AuNRs and $\mathrm{SiO}_{2}$-AuNRs impact on cellular viability of HeLa (A), FY-II (B), SH-SY5Y (C) and HUVEC (D) cells as determined by CellTiter-Glo ${ }^{\circledR}$ assay. Notes: AuNRs and $\mathrm{SiO}_{2}$-AuNRs were incubated with cells for $24 \mathrm{~h}$ at $0.7-12 \mu \mathrm{g} / \mathrm{ml}$. Control group was treated with media.

Abbreviations: AuNRs, gold nanorods; $\mathrm{SiO}_{2}$-AuNRs, gold nanorods functionalized with silica; FY-II, fibroblast cells; HeLa, cervical cancer cells; $\mathrm{SH}-\mathrm{SY} 5 Y$, neuroblastoma cells; HUVEC, human umbilical vein endothelial cell.

These results demonstrate that the formation of free radicals is significantly induced by AuNRs and $\mathrm{SiO}_{2}$-AuNRs in different cell lines. Based on these obtained results, for 12 hours, a negligible increase in the production of hydrogen peroxide $\left(\mathrm{H}_{2} \mathrm{O}_{2}\right)$, hydroxyl radical $(\bullet \mathrm{OH})$, and superoxide anion $\left(\mathrm{O}_{2}{ }^{--}\right)$ was observed from the AuNRs, whereas the production from the $\mathrm{SiO}_{2}$-AuNRs was almost similar to the control. After an 18-hour incubation period, the AuNRs increased ROS production by an average of $20 \%$. Cells containing $\mathrm{SiO}_{2}$-AuNRs exhibited a slight increase in ROS by around 5\%, which was similar to the control. Finally, after 24 hours of incubation, it was observed that cells treated with AuNRs produced a higher
A

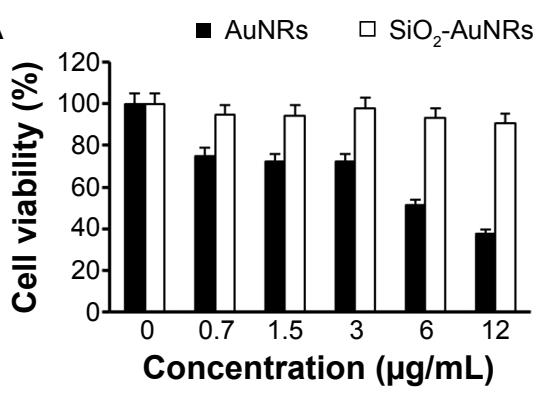

C

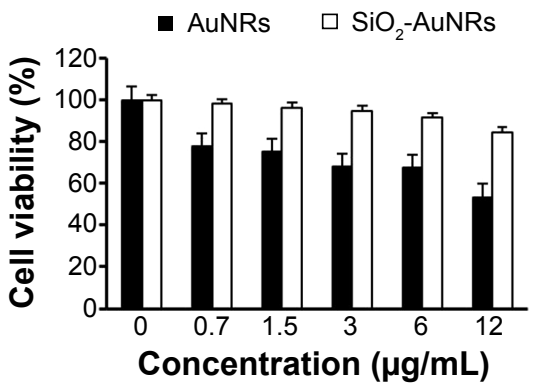

B

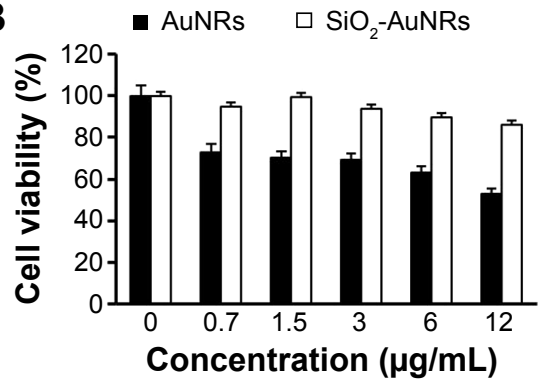

D

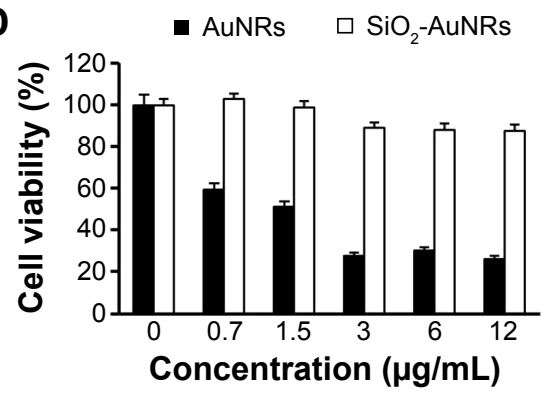

Figure 6 Cell viability of HeLa (A), FY-II (B), SH-SY5Y (C) and HUVEC (D) cells after exposure to increasing doses of AuNRs and SiO 2 -AuNRs for 24 h, as determined by MTT assay.

Note: The data represents AuNRs to be significantly toxic than $\mathrm{SiO}_{2}$-AuNRs.

Abbreviations: AuNRs, gold nanorods; $\mathrm{SiO}_{2}-\mathrm{AuNRs}$, gold nanorods functionalized with silica; FY-I I, fibroblast cells; HeLa, cervical cancer cells; $\mathrm{SH}-\mathrm{SY} 5 Y$, neuroblastoma cells; HUVEC, human umbilical vein endothelial cell; MTT, 3-(4,5-dimethyl-2-thiazolyl)-2,5-diphenyltetrazolium bromide. 
A

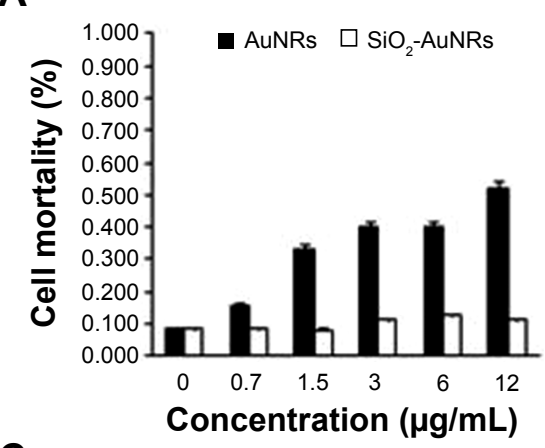

C

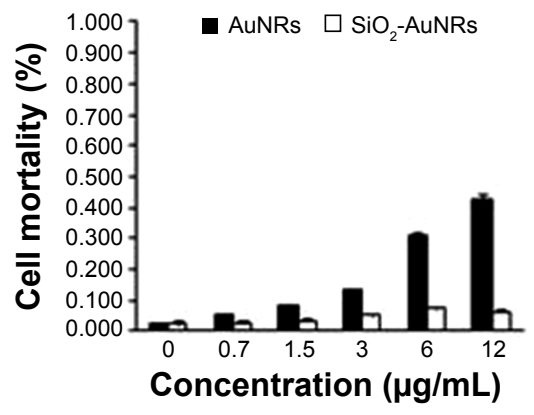

B
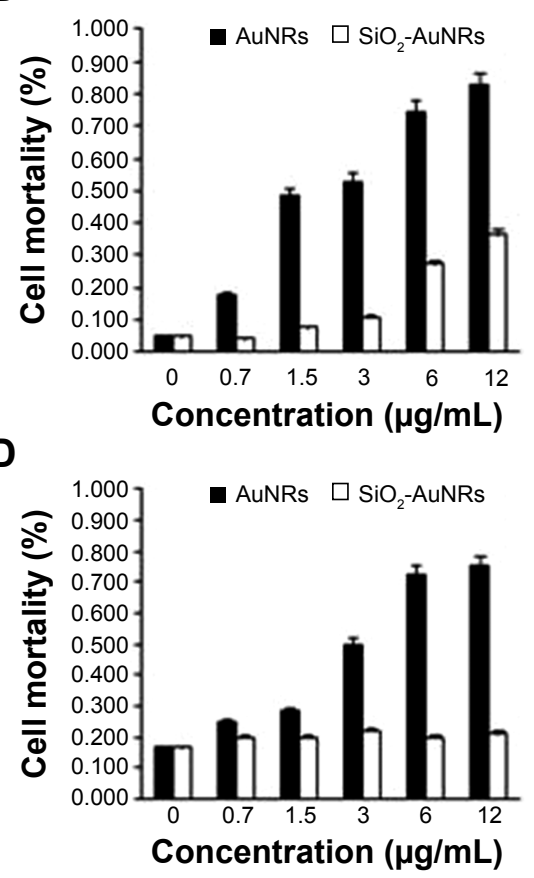

Figure 7 Cell mortality assay of HeLa (A), FY-II (B), SH-SY5Y (C) and HUVEC (D) cells.

Note: AuNRs and $\mathrm{SiO}_{2}$-AuNRs having concentration of $0.7,1.5,3,6$ and $12 \mu \mathrm{g} / \mathrm{ml}$ were exposed to the cells for $24 \mathrm{~h}$. The cell mortality was measured with trypan blue. The control group was treated with media only.

Abbreviations: AuNRs, gold nanorods; $\mathrm{SiO}_{2}-\mathrm{AuNRs}$, gold nanorods functionalized with silica; FY-I I, fibroblast cells; HeLa, cervical cancer cells; SH-SY5Y, neuroblastoma cells; HUVEC, human umbilical vein endothelial cell.

percentage of $\mathrm{H}_{2} \mathrm{O}_{2}, \bullet \mathrm{OH}$, and $\mathrm{O}_{2}^{\bullet-}$ than those treated with $\mathrm{SiO}_{2}$-AuNRs did, as shown in Figure 8, which led to cellular death. AuNRs produced almost $60 \%$ of free radicals in all cell lines, whereas the production induced by the $\mathrm{SiO}_{2}$-AuNRs remained around $20 \%$, resulting in greater cellular viability.

\section{Effects of the protein corona on NRs}

To present a comprehensive characterization, MS analysis was performed to determine the biomolecular entities formed by dispersing AuNRs and $\mathrm{SiO}_{2}$-AuNRs into the cell culture medium. Table 1 reports the number of proteins attached to AuNRs and $\mathrm{SiO}_{2}$-AuNRs incubated in DMEM and RPMI.

This analysis showed that in both types of cell culture medium (DMEM and RPMI), the total number of proteins attached to the AuNR surface was less than that of the $\mathrm{SiO}_{2}$-AuNR surface. As previously shown, ${ }^{16}$ this nano-bio interface is due to three dynamically interacting components: 1) the surface of NRs whose characteristics are determined

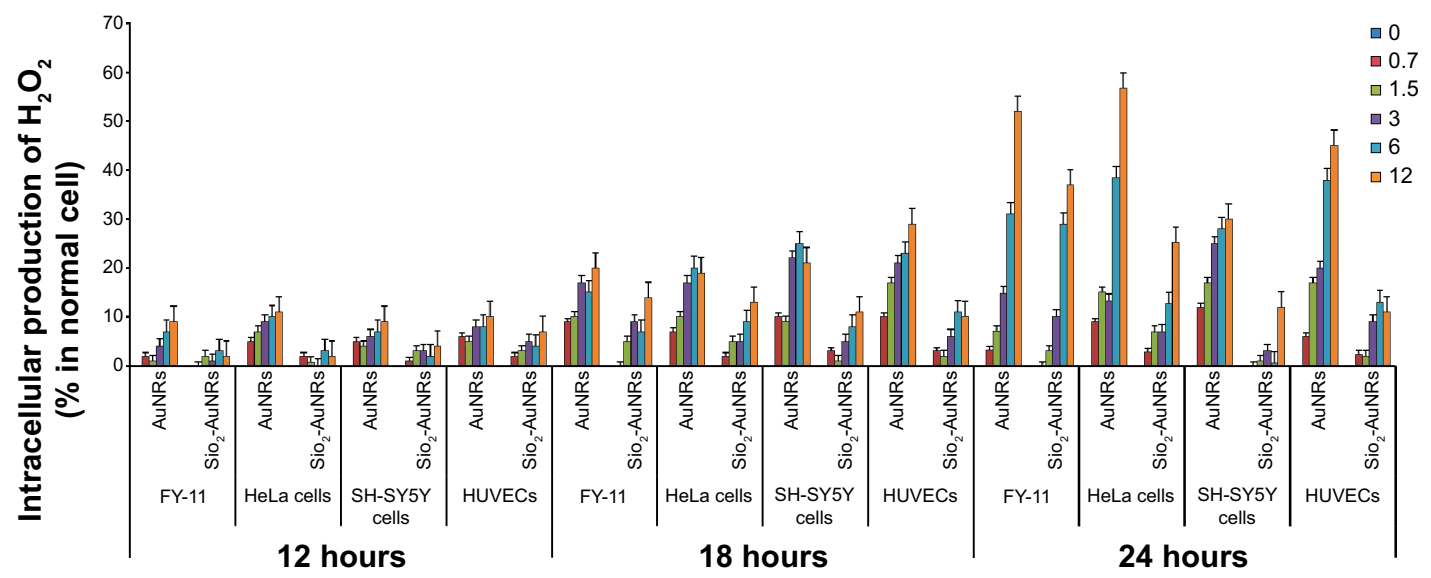

Figure 8 The expression of ROS in FY-II, HeLa, SH-SY5Y and HUVEC cells exposed for 12, 18 and 24 h to different concentrations of AuNRs and SiO - -AuNRs. Notes: AuNRs and $\mathrm{SiO}_{2}$-AuNRs concentrations are measured in $\mu \mathrm{g} / \mathrm{ml}$. Bar graph indicates statistically significant differences between AuNRs and $\mathrm{SiO}{ }_{2}$-AuNRs. All cells with media served as controls.

Abbreviations: AuNRs, gold nanorods; $\mathrm{SiO}_{2}$-AuNRs, gold nanorods functionalized with silica; FY-II, fibroblast cells; HeLa, cervical cancer cells; SH-SY5Y, neuroblastoma cells; HUVECs, human umbilical vein endothelial cells; ROS, reactive oxygen species. 
Table I Total number of proteins attached to the surface of AuNRs and $\mathrm{SiO}_{2}$-AuNRs

\begin{tabular}{lllll}
\hline Medium & Sample & Total proteins & Within criteria & Without criteria \\
\hline DMEM & AuNRs & 146 & 102 & 44 \\
& & 100 & 66 & 34 \\
RPMI & $\mathrm{SiO}_{2}$-AuNRs & 153 & 106 & 47 \\
& & 122 & 84 & 42 \\
\hline
\end{tabular}

Abbreviations: DMEM, Dulbecco's Modified Eagle's Medium; RPMI, Roswell Park Memorial Institute; AuNRs, gold nanorods; SiO ${ }_{2}$-AuNRs, gold nanorods functionalized with silica.

by their physiochemical composition, 2) the changes that occur following the solid-liquid interface when the particle interacts with components in the surrounding medium, and 3 ) the contact area of the solid-liquid interface with its biological substrates. Specific NR properties have been shown to greatly contribute to the NR interactions with medium. ${ }^{17}$ For example, certain NR properties may result in increased adsorption of ions, proteins, organic materials, and detergents, which permits double-layer formation and minimizes the free surface energy by surface modification. There are several factors affecting the protein corona formation, including protein-AuNRs interactions, protein-protein interactions, and protein-medium interactions. ${ }^{18}$

As shown in Figure 9, the DMEM and RPMI mediums encouraged the attachment of a comparable number of proteins. The major difference observed was with the surface
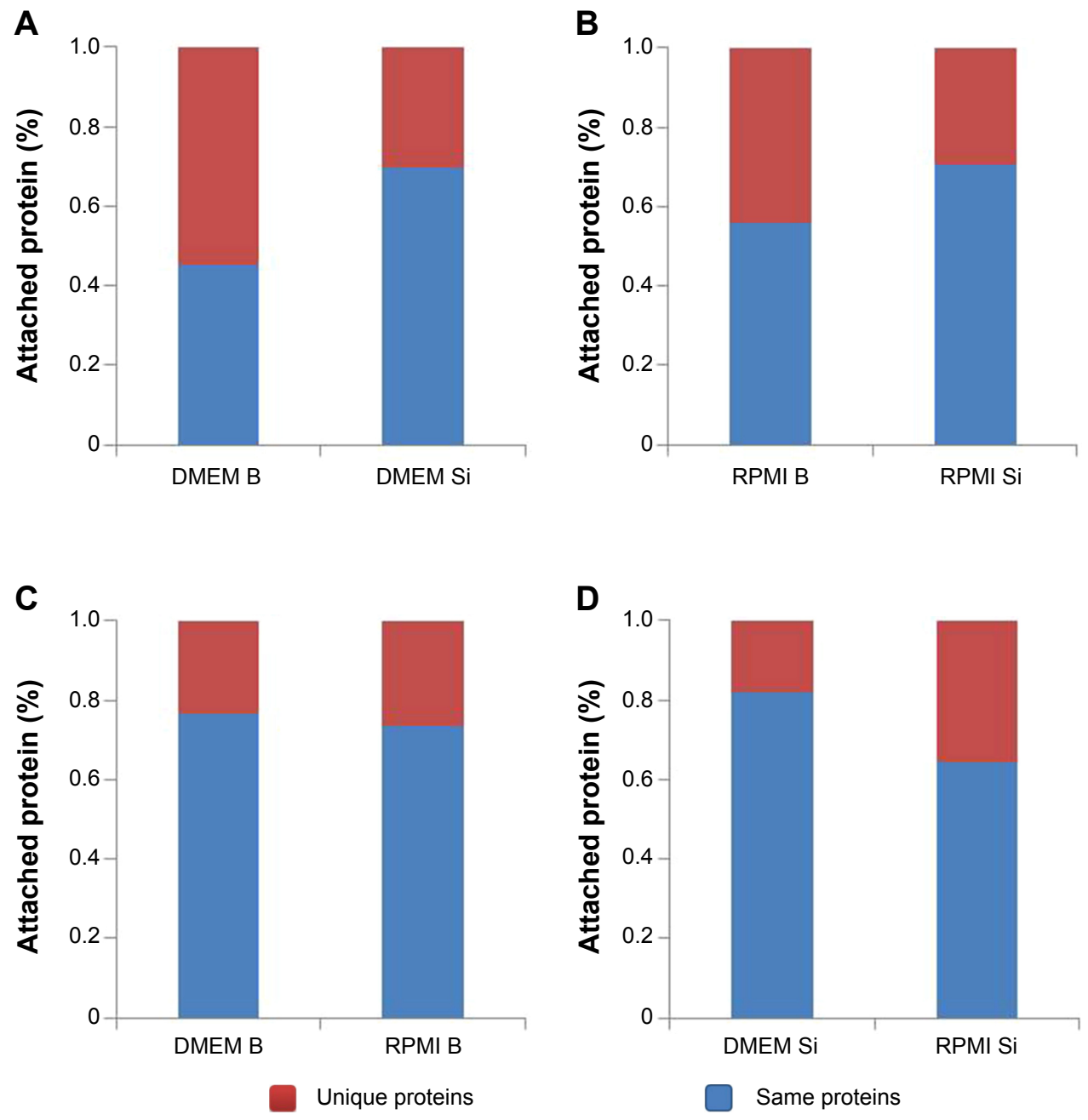

Figure 9 Proteins attachment on AuNRs and $\mathrm{SiO}_{2}$-AuNRs surfaces incubated in DMEM and RPMI medium for I h.

Notes: (A) Represents the attachment of larger numbers of unique proteins (50\%) on DMEM incubated AuNRs, whereas on DMEM incubated SiO - -AuNRs a lesser number of unique proteins are attached. (B) Represents the attachment of a larger number of unique proteins (50\%) on RPMI medium incubated AuNRs, whereas on RPMI medium incubated $\mathrm{SiO}_{2}$-AuNRs a lesser number of unique proteins are attached. (C) and (D) Represents the number of unique proteins attached on DMEM and RPMI medium incubated AuNRs and $\mathrm{SiO}_{2}$-AuNRs, which are almost similar. Hence, it is apparent that the attachment solely depends on the surface properties and charges, rather than differences in the medium. Abbreviations: DMEM, Dulbecco's Modified Eagle's Medium; RPMI, Roswell Park Memorial Institute; B, bare; Si, silica. 
charges, as the number of unique proteins attached in the AuNRs increases by approximately $50 \%$ more than that of the $\mathrm{SiO}_{2}$-AuNRs. The difference in surface charge encouraged the formation of different hybrid bionanostructures that, in turn, exerted different biological effects when interacting with cells. Furthermore, as shown in Figure 10, the unique proteins that got attached to the AuNRs were cell matrix adhesion proteins. These cell matrix adhesion proteins were present in DMEM- and RPMI-incubated AuNRs, whereas they were absent in DMEM- and RPMI-incubated $\mathrm{SiO}_{2}-$ AuNRs.

The main species of cell matrix adhesion proteins that were adsorbed onto the metallic NR surfaces were identified as important proteins involved in key biological processes (Table 2), which included alpha actinin 1 (actin-binding proteins, several roles in several cells), fibronectin (extracellular matrix glycoprotein, binds to integrins and plays a role in cell adhesion, growth, migration, differentiation, wound healing, and embryonic growth), angiotensin (peptide hormone, causes vasoconstriction and increase in blood pressure), nidogen (basement membrane glycoprotein, plays a role in cell-extracellular matrix interactions), and vitronectin (glycoprotein found in serum and extracellular matrix, plays a role in cell adhesion and spreading).

\section{Discussion}

Interest in the use of AuNRs for biomedical applications has grown due to their unique physiochemical properties; however, their current use has been limited because of major concerns over their toxicity. AuNRs are toxic to cells due to the presence of CTAB, which is required for AuNR stabilization. Therefore, surface functionalization, such as with $\mathrm{SiO}_{2}$, has been used in an effort to reduce AuNR toxicity.

For AuNRs, the intensity of the longitudinal plasmon band corresponding to the long axis of the NRs has been shown to be much higher than that of the transverse plasmon band corresponding to the short axis of the NRs, because of the enhanced surface electric field due to surface plasmon excitation. ${ }^{15}$
A

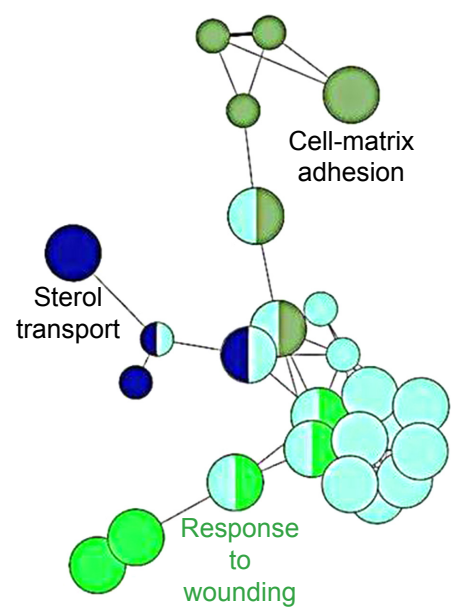

C

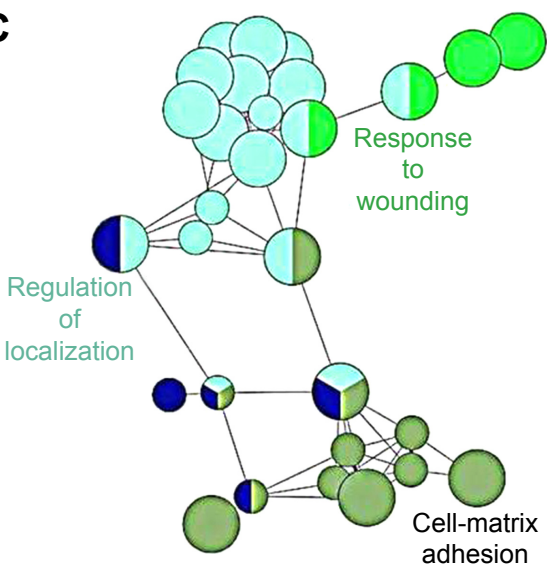

B

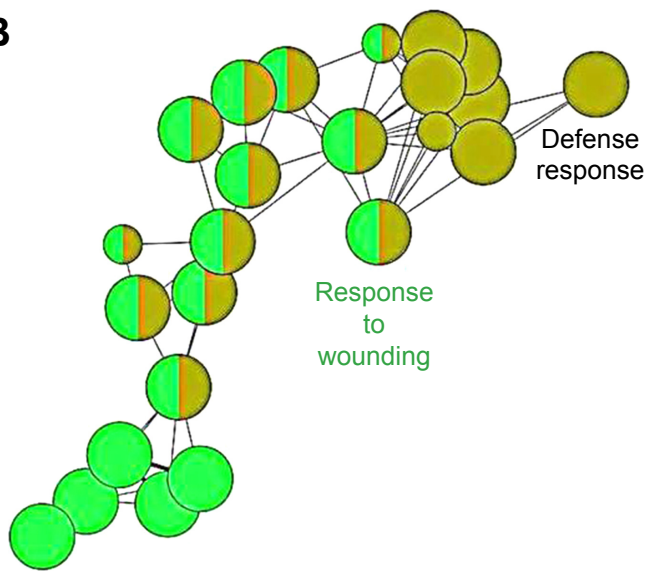

D

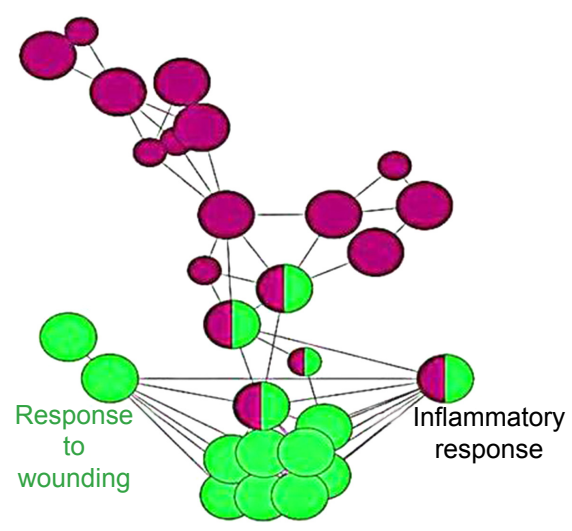

Figure 10 Unique proteins attached on the surface of $\operatorname{DMEM}(\mathbf{A}, \mathbf{B})$ and RPMI medium (C, D) incubated AuNRs and $\mathrm{SiO}_{2}$-AuNRs.

Notes: (A) Represents the presence of cell matrix adhesion proteins on AuNRs; (B) represents the absence of cell matrix adhesion proteins on SiO ${ }_{2}$-AuNRs; (C) represents the presence of cell matrix adhesion proteins on AuNRs; (D) represents the absence of cell matrix adhesion proteins on $\mathrm{SiO}_{2}$-AuNRs.

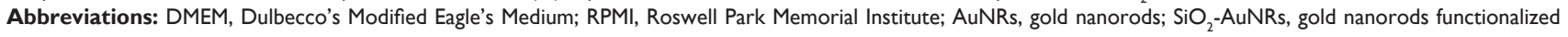
with silica. 
Table 2 List of cell matrix adhesion proteins attached to AuNRs and $\mathrm{SiO}_{2}$-AuNRs surfaces

\begin{tabular}{|c|c|c|c|c|}
\hline$\underline{\text { Protein }}$ & DMEM AuNRs & DMEM SiO $_{2}$-AuNRs & RPMI AuNRs & $\mathrm{RPMI} \mathrm{SiO}_{2}$-AuNRs \\
\hline Alpha-actinin-I & 10.21 & Absent & 10.18 & Absent \\
\hline Fibronectin & 460.32 & 20.16 & 530.35 & 240.32 \\
\hline Angiotensin & 140.33 & 60.26 & 190.32 & 80.29 \\
\hline Nidogen & 10.15 & Absent & 20.22 & Absent \\
\hline Vitronectin & 90.33 & 70.29 & 110.33 & 80.33 \\
\hline
\end{tabular}

Abbreviations: DMEM, Dulbecco's Modified Eagle's Medium; RPMI, Roswell Park Memorial Institute; AuNRs, gold nanorods; SiO ${ }_{2}$-AuNRs, gold nanorods functionalized with silica.

Therefore, in the case of $\mathrm{SiO}_{2}-\mathrm{AuNRs}$, the shift in the longitudinal plasmon band is larger than that of the transverse band, which is at a wavelength close to the characteristic band of Au nanoparticles of similar diameter.

Every particle in a mixture carries some charge, which is typically negative rather than positive. This is attributed to the presence of chemical groups on the surface of the particle, which are ionized to form a charged surface. Sometimes, ions with an opposite charge may be adsorbed to the surface, and at other times chemical compounds may be intentionally added to yield a specific charge. In this study, CTAB acts as a chemical compound that generates the charge for the AuNRs. Since the CTAB-stabilized AuNRs possess a highly positive surface charge, the wrapping of negative ions around the metal is strongly favored. Hence, a $\mathrm{SiO}_{2}$ coating over the AuNRs was formed, and zeta potential analysis was performed to confirm the coating of $\mathrm{SiO}_{2}$-AuNRs.

In the present study, a visible difference in cell viability was observed based on the results of the viability assays used, as different mechanisms were involved. For the MTT assay, water-soluble MTT was converted to an insoluble formazan crystal. The formazan was then solubilized by inorganic solvent, and the concentration was determined by determining the optical density at $570 \mathrm{~nm}$. Alternatively, for the CellTiter-Glo ${ }^{\circledR}$ assay, a homogeneous method based on the amount of adenosine triphosphate (ATP) present, which indicates the presence of metabolically active cells, was used to determine the number of viable cells.

Typically, polycationic materials exhibit higher cytotoxicity. AuNRs stabilized with CTAB and washed once with water by centrifugation showed strong cytotoxicity due to free $\mathrm{CTAB}$ remaining in the solution. However, in the case of the $\mathrm{SiO}_{2}$-AuNRs, more than $70 \%$ cell viability was observed even at the highest concentrations, indicating that the removal of excess CTAB and modification with $\mathrm{SiO}_{2}$ contributed to a significant decrease in cytotoxicity. The $\mathrm{SiO}_{2}$-AuNRs exhibited lower toxicity, which is essential for biomedical applications using AuNRs. In addition, the absence of CTAB on the AuNR surfaces has been shown to affect biological processes inside the cells, while binding to the cell membrane. ${ }^{19}$

Since material properties affect the kinetics of cell death, the mechanisms of nanomaterial-mediated cell toxicity may vary depending on the composition of the material each cell type interacts with. ROS generation has been suggested as an initial cellular response to nanomaterial internalization and subsequent cell death. In this study, the nanomaterialmediated cell responses prior to cell death, specifically the production of intracellular ROS, were measured at 6 hours via the DHR assay. Our results showed that AuNRs increased the production of ROS in all cells by $60 \%$, depending on the time, whereas ROS production for the $\mathrm{SiO}_{2}$-AuNRs was negligible. These results indicated that $\mathrm{SiO}_{2}$ scavenged the production of the ROS. The mechanism for the production of free radicals and its relation to toxicity are described as follows.

Typically, ROS generated by cells within an enclosed environment may easily turn into a source of cell and tissue injury. $\mathrm{O}_{2}$ is essential for human survival, and aerobic energy metabolism depends upon oxidative phosphorylation, which plays a vital role through which the oxidoreduction energy of mitochondrial electron transport is eventually converted to the high-energy phosphate bond of ATP. Aerobic organisms use $\mathrm{O}_{2}$ as the final electron acceptor for mitochondrial cytochrome c oxidase, which is able to catalyze the four electron reduction of $\mathrm{O}_{2}$, leading to $\mathrm{H}_{2} \mathrm{O}$ formation (Equation 1). During mitochondrial oxidative phosphorylation, and other electron transfer reactions, including those of the superoxide anion $\left(\mathrm{O}_{2}{ }^{--}\right)$, hydrogen peroxide $\left(\mathrm{H}_{2} \mathrm{O}_{2}\right)$ and hydroxyl radicals $(\bullet \mathrm{OH})$ can be formed within cells (Equation 2). These reactive $\mathrm{O}_{2}$ metabolites are usually collectively referred to as ROS, and their generation in a biological environment exposes most living organisms to the so-called "oxygen paradox". $\mathrm{O}_{2}$ is essential for life, but it is also potentially hazardous, since ROS may become a source of cell and tissue injury.

\section{Equation I}

In a human body, four electron reduction reactions occur, leading from $\mathrm{O}_{2}$ to $\mathrm{H}_{2} \mathrm{O}$ production: 
1. $\mathrm{O}_{2}+\mathrm{e}^{-} \rightarrow \mathrm{O}_{2}^{--}\left(+\mathrm{H}^{+} \leftrightarrow \mathrm{HO}_{2}^{\cdot}\right)$

2. $\mathrm{O}_{2}{ }^{\cdot-}+\mathrm{e}^{-} \rightarrow\left(\mathrm{O}_{2}{ }^{2-}+2 \mathrm{H}^{+}\right) \rightarrow \mathrm{H}_{2} \mathrm{O}_{2}$

3. $\mathrm{H}_{2} \mathrm{O}_{2}+\mathrm{e}^{-} \rightarrow \cdot \mathrm{OH}+\mathrm{OH}^{-}$

4. $\mathrm{OH}+\mathrm{e}^{-} \rightarrow+\mathrm{H}^{+} \rightarrow \mathrm{H}_{2} \mathrm{O}$.

\section{Equation 2}

When the human body is exposed to a foreign material (metal nanoparticles), then carbon-centered free radicals are generated by interaction with ROS:

1. $\mathrm{R}-\mathrm{H}+{ }^{\bullet} \mathrm{OH} \rightarrow \mathrm{R}^{\bullet}+\mathrm{H}_{2} \mathrm{O}$ (organic radical)

2. $\mathrm{R}^{\bullet}+\mathrm{O}_{2} \rightarrow \mathrm{ROO}^{\bullet}$ (peroxyl radical)

3. $\mathrm{ROO}^{\bullet}+\mathrm{R}-\mathrm{H} \rightarrow \mathrm{ROOH}+\mathrm{R}^{\bullet}$ (organic peroxide)

4. $\mathrm{ROOH}+$ nanoparticle $\rightarrow \mathrm{RO}^{\bullet}+{ }^{-} \mathrm{OH}+$ nanoparticle (alkoxy radical).

Thus, the free radicals produced may be very dangerous, leading to cell death. In this study, the results obtained were different for each cell type; however, the production of intracellular ROS increased due to the presence of AuNRs, while $\mathrm{SiO}_{2}$-AuNRs showed scavenging properties.

Based on the principles involved in ROS production, the question arises of what induces increased free-radical production within cells. Recently, many researchers have addressed the relationship between nanomaterials and biological fluid interaction. A layer formed over the nanomaterial has been defined as the "corona". ${ }^{20}$ When NRs enter a biological fluid (medium), they are coated with proteins that may undergo conformational changes, leading to the exposure of new epitopes, altered function, and/or avidity effects..$^{18}$ The concept of the NR-protein corona is important for tuning the surface properties, charges, resistance to aggregation, and toxicity of NRs. Notably, in this study, we showed that the interactive NR surface may be prebound to chemical substances that reflect its prior history and could subsequently influence its protein adsorption kinetics.

\section{Conclusion}

The results of this study demonstrate that the AuNRs due to the presence of CTAB molecules are the source of toxicity. Providing a coating over the $\mathrm{CTAB}$-coated AuNRs with alkoxysilane is one way to prevent toxicity, which explains why the overcoated rods examined in this work were far more biocompatible.

In addition, we analyzed the protein corona formed over AuNRs and $\mathrm{SiO}_{2}$-AuNRs to determine any significant differences and to identify the cause of toxicity observed on the two types of NRs. Based on our hypothesis, we confirmed with MS that two different groups of protein corona were formed on the AuNRs and $\mathrm{SiO}_{2}$-AuNRs, respectively. The corona formation completely depended on the material surface properties. The MS data suggested the presence of cell matrix adhesion proteins on the AuNRs, and the absence of those proteins on the $\mathrm{SiO}_{2}$-AuNRs. Cell matrix adhesion proteins such as immunoglobulin are associated with the recognition and phagocytosis of NRs into the cells. The adsorbed proteins regulate the NR-cellular interactions, thus making them toxic or nontoxic to cells. In addition, different reports have shown that the corona could force the toxicity of materials. ${ }^{20}$ The presence of such proteins could be the reason for excessive free-radical production in cells leading to cell death. The list of proteins involved in corona formation are mentioned in the supplementary information. Hence, we concluded that the biological impact of the AuNRs was not exactly associated with their properties but associated with the attributes of the corona NR complexes. Further studies of the protein corona and its behavior could provide a clearer picture of this relationship.

\section{Acknowledgments}

This work was supported by the grants of National Research Foundation of Korea (NRF), funded by Korean government (MEST) (2012R1A2A2A03046819), and (2013R1A1A2005329). The authors would like to thank Kyu Hwan Shim for his help in generating ClueGo figures.

\section{Disclosure}

The authors report no conflicts of interest in this work.

\section{References}

1. Alkilany AM, Nagaria PK, Hexel CR, Shaw TJ, Murphy CJ, Wyatt MD Cellular uptake and cytotoxicity of gold nanorods: molecular origin of cytotoxicity and surface effects. Small. 2009;5(6):701-708.

2. Hauck TS, Ghazani AA, Chan WC. Assessing the effect of surface chemistry on gold nanorod uptake, toxicity, and gene expression in mammalian cells. Small. 2008;4(1):153-159.

3. Takahashi H, Niidome T, Kawano T, Yamada S, Niidome Y. Surface modification of gold nanorods using layer-by-layer technique for cellular uptake. J Nanopart Res. 2008;10:221-228.

4. Kleps Conner SD, Schmid SL. Regulated portals of entry into the cell. Nature. 2003;422(6927):37-44.

5. Marquis BJ, Love SA, Braun KL, Haynes CL. Analytical methods to assess nanoparticle toxicity. Analyst. 2009;134(3):425-439.

6. Chang Y, Yang ST, Liu JH, Dong E, Wang Y, Cao A, Liu Y, Wang H. In vitro toxicity evaluation of graphene oxide on A549 cells. Toxicol Lett. 2011;200(3):201-210.

7. Lee JY, Park W, Yi DK. Immunostimulatory effects of gold nanorod and silica-coated gold nanorod on RAW 264.7 mouse macrophages. Toxicol Lett. 2012;209(1):51-57.

8. Tedesco S, Doyle H, Blasco J, Redmond G, Sheehan D. Oxidative stress and toxicity of gold nanoparticles in Mytilus edulis. Aquat Toxicol. 2010; 100(2):178-186.

9. Wang F, Gao F, Lan M, Yuan H, Huang Y, Liu J. Oxidative stress contributes to silica nanoparticle-induced cytotoxicity in human embryonic kidney cells. Toxicol In Vitro. 2009;23(5):808-815.

10. Sau TK, Murphy CJ. Seeded high yield synthesis of short Au nanorods in aqueous solution. Langmuir. 2004;20(15):6414-6420. 
11. Pérez-Juste J, Correa-Duarte MA, Liz-Marzán LM. Silica gels with tailored, gold nanorod-driven optical functionalities. Applied Surface Science. 2004;226:137-143.

12. Cong H, Toftegaard R, Arnbjerg J, Ogilby PR. Silica-coated gold nanorods with a gold overcoat: controlling optical properties by controlling the dimensions of a gold-silica-gold layered nanoparticle. Langmuir. 2010;26(6):4188-4195.

13. Gorelikov I, Matsuura N. Single-step coating of mesoporous silica on cetyltrimethyl ammonium bromide-capped nanoparticles. Nano Lett. 2008;8(1):369-373.

14. Obare SO, Jana NR, Murphy CJ. Preparation of polystyrene- and silicacoated gold nanorods and their use as templates for the synthesis of hollow nanotubes. Nano Lett. 2001;1:601-603.

15. Jain PK, Lee KS, El-Sayed IH, El-Sayed MA. Calculated absorption and scattering properties of gold nanoparticles of different size, shape, and composition: applications in biological imaging and biomedicine. J Phys Chem B. 2006;110(14):7238-7248.
16. Tansey W, Ke S, Cao XY, Pasuelo MJ, Wallace S, Li C. Synthesis and characterization of branched poly(L-glutamic acid) as a biodegradable drug carrier. J Control Release. 2004;94(1):39-51.

17. Guo D, Wu C, Li X, Jiang H, Wang X, Chen B. In vitro cellular uptake and cytotoxic effect of functionalized nickel nanoparticles on leukemia cancer cells. J Nanosci Nanotechnol. 2008;8(5):2301-2307.

18. Nel AE, Mädler L, Velegol D, et al. Understanding biophysicochemical interactions at the nano-bio interface. Nat Mater. 2009;8(7):543-557.

19. Harris JM, Chess RB. Effect of pegylation on pharmaceuticals. Nat Rev Drug Discov. 2003;2(3):214-221.

20. Lesniak A, Fenaroli F, Monopoli MP, Åberg C, Dawson KA, Salvati A. Effects of the presence or absence of a protein corona on silica nanoparticle uptake and impact on cells. ACS Nano. 2012;6(7):5845-5857. 


\section{Supplementary materials}

As shown in this section, a list of proteins involved in the protein corona layer due to the incubation of gold nanorods (AuNRs) (bare) and gold nanorods functionalized with silica ( $\mathrm{SiO}_{2}$-AuNRs) ( $\mathrm{Si}$ ) in Dulbecco's Modified Eagle's Medium (DMEM) or Roswell Park Memorial Institute (RPMI) medium is provided. As shown in the tables, "common proteins" indicates proteins involved in both DMEM-bare and DMEM-Si (Tables S3, S4, S7 and S8). On the other hand, "uncommon proteins" indicates unique proteins involved in either DMEM-bare or DMEM-Si. Similar designations are specified for the RPMI samples (Tables S5, S6, S9 and S10).

Here, we compared DMEM-bare with DMEM-Si (Table S1) (to show the difference between "bare" and "Si" in DMEM), RPMI-bare with RPMI-Si (Table S2) (to show the difference between "bare" and "Si" in RPMI), DMEMbare with RPMI-bare (Table S9) (to show the difference between "DMEM" and "RPMI" in bare), and DMEM-Si with RPMI-Si (to show the difference between "DMEM" and "RPMI" in Si) (Table S10).

Table SI Protein corona list of DMEM-bare and DMEM-Si

\begin{tabular}{|c|c|}
\hline DMEM-bare & DMEM-Si \\
\hline Alpha-I-antiproteinase precursor & PREDICTED: apolipoprotein B \\
\hline Protein AMBP precursor & Complement $\mathrm{C} 3$ preproprotein \\
\hline Talin- I & Serum albumin precursor \\
\hline Thyroglobulin precursor & Alpha-2-macroglobulin \\
\hline Apolipoprotein E precursor & Antithrombin-III precursor \\
\hline Alpha-2-antiplasmin precursor & Apolipoprotein E precursor \\
\hline Apolipoprotein A-I preproprotein & Inter-alpha-trypsin inhibitor heavy chain $\mathrm{H} 2$ \\
\hline Hemoglobin fetal subunit beta & Apolipoprotein A-I preproprotein \\
\hline Coagulation factor $V$ precursor & Fibulin-I \\
\hline Hyaluronan-binding protein 2 & Alpha-I-antiproteinase precursor \\
\hline C4b-binding protein alpha chain precursor & Alpha-2-HS-glycoprotein precursor \\
\hline Kininogen-2 isoform II & Complement $\mathrm{C} 4$ \\
\hline Complement component $\mathrm{C} 9$ precursor & Periostin \\
\hline PREDICTED: apolipoprotein B & Inter-alpha-trypsin inhibitor heavy chain $\mathrm{H} 3$ precursor \\
\hline Tubulin, beta I & Hemoglobin subunit alpha \\
\hline PREDICTED: similar to complement component 4A & Vitronectin \\
\hline PREDICTED: heparan sulfate proteoglycan 2 & Heparin cofactor 2 \\
\hline Hemoglobin subunit beta & Prothrombin \\
\hline Fibrinogen alpha chain precursor & Inter-alpha-trypsin inhibitor heavy chain $\mathrm{H} 4$ precursor \\
\hline Hemoglobin subunit alpha & Hemoglobin fetal subunit beta \\
\hline Hypothetical protein LOC5I 0860 & Angiotensinogen \\
\hline Heat shock protein HSP 90 -alpha & PREDICTED: complement component 4 binding protein, alpha chain-like \\
\hline Serpin A3-I precursor & Gelsolin isoform a \\
\hline Factor XIla inhibitor precursor & Protein AMBP precursor \\
\hline Actin, aortic smooth muscle & Fetuin-B precursor \\
\hline Tubulin alpha-4A chain & Lipopolysaccharide-binding protein precursor \\
\hline Kininogen-2 isoform I & Plasma serine protease inhibitor precursor \\
\hline Inter-alpha-trypsin inhibitor heavy chain $\mathrm{H} 4$ precursor & Complement component $\mathrm{C} 9$ precursor \\
\hline Mannan-binding lectin serine protease I & Actin, aortic smooth muscle \\
\hline Apolipoprotein M & Coagulation factor XIII A chain precursor \\
\hline Fibrinogen beta chain & Talin-I \\
\hline Tenascin- $X$ & PREDICTED: apolipoprotein B \\
\hline PREDICTED: complement component 4 binding protein, alpha chain-like & Serotransferrin precursor \\
\hline Collagen alpha-I (XII) chain & Hemoglobin subunit beta \\
\hline Heat shock protein HSP 90-beta & Alpha-2-antiplasmin precursor \\
\hline Tubulin beta- 5 chain & Phosphoglycerate kinase I \\
\hline Fibromodulin & Inter-alpha-trypsin inhibitor heavy chain $\mathrm{HI}$ precursor \\
\hline Fetuin-B precursor & Actin, cytoplasmic I \\
\hline Lumican precursor & L-lactate dehydrogenase B chain \\
\hline Alpha-actinin-I & Apolipoprotein A-II precursor \\
\hline
\end{tabular}


Table SI (Continued)

\begin{tabular}{|c|c|}
\hline DMEM-bare & DMEM-Si \\
\hline Vitamin D-binding protein precursor & Fibronectin \\
\hline Neuropilin-I & Hypothetical protein LOC5I0860 \\
\hline Echinoderm microtubule-associated protein-like 5 & Heat shock protein HSP 90-beta \\
\hline PREDICTED: alpha-2-macroglobulin-like, partial & Fermitin family homolog 3 \\
\hline Aggrecan core protein & Phospholipid transfer protein \\
\hline PREDICTED: GLIS family zinc finger 3, partial & Pyruvate kinase isozymes $\mathrm{MI} / \mathrm{M} 2$ \\
\hline Plasma serine protease inhibitor precursor & Adenosylhomocysteinase \\
\hline PREDICTED: calcium channel, voltage-dependent, & Complement component 8 , beta polypeptide \\
\hline \multicolumn{2}{|l|}{ L type, alpha IS subunit-like } \\
\hline Myosin, heavy chain 9 , nonmuscle & Kininogen-2 isoform II \\
\hline Glyceraldehyde-3-phosphate dehydrogenase & Kelch-like ECH-associated protein I \\
\hline Caspase- 14 & Alpha-enolase \\
\hline tRNA-dihydrouridine synthase I-like & PREDICTED: similar to complement component 4A \\
\hline Myosin- II & Apolipoprotein M \\
\hline PREDICTED: KRAB-A domain containing 2 & Glyceraldehyde-3-phosphate dehydrogenase \\
\hline Thrombospondin-3 & Transmembrane and coiled-coil domain-containing protein 2 \\
\hline Neuropilin-2 & Glyceraldehyde-3-phosphate dehydrogenase, testis-specific \\
\hline Beta-casein precursor & Probable arginyl-tRNA synthetase, mitochondrial precursor \\
\hline PREDICTED: collagen, type VI, alpha 3-like isoform 4 & Serpin A3-I precursor \\
\hline Sucrase-isomaltase, intestinal & Vitamin D-binding protein precursor \\
\hline Transmembrane and coiled-coil domain-containing protein 2 & L-lactate dehydrogenase C isoform I \\
\hline Complement factor B precursor & Nucleolar GTP-binding protein 2 \\
\hline Interleukin-I beta precursor & Thyroxine-binding globulin precursor \\
\hline PREDICTED: NIMA (never in mitosis gene a)-related kinase II & Heat shock protein HSP 90-alpha \\
\hline Coagulation factor $X$ & C4b-binding protein alpha chain precursor \\
\hline SPARC-like protein I & Neutrophil cytosol factor I \\
\hline PREDICTED: FYVE and coiled-coil domain-containing protein I-like & Apolipoprotein D precursor \\
\hline PREDICTED: thiolester containing protein II-like & Thrombospondin-I precursor \\
\hline Carbohydrate sulfotransferase 3 & Zinc finger protein 668 \\
\hline PREDICTED: zinc finger protein 347-like & PREDICTED: mcg I44546-like \\
\hline C-type lectin domain family II member A & Dynein heavy chain 2 , axonemal \\
\hline Terminal uridylyltransferase 4 & Coagulation factor $\mathrm{V}$ precursor \\
\hline Nucleolar GTP-binding protein 2 & Leucine-rich repeat-containing protein 49 \\
\hline Alpha-SI-casein precursor & Tyrosine-protein kinase BAZIB \\
\hline Collectin-II precursor & Alpha-SI-casein precursor \\
\hline Mannan-binding lectin serine protease 2 & Coiled-coil domain-containing protein 7I \\
\hline $\mathrm{N}$-acetylated-alpha-linked acidic dipeptidase 2 & Pigment epithelium-derived factor precursor \\
\hline Pentraxin-related protein PTX3 precursor & Clusterin preproprotein \\
\hline 6-Phosphogluconate dehydrogenase, decarboxylating & $\begin{array}{l}\text { PREDICTED: PDS5, regulator of cohesion maintenance, } \\
\text { homolog B (Saccharomyces cerevisiae) }\end{array}$ \\
\hline Nidogen-I & Splicing factor 3B subunit 2 \\
\hline Mitochondrial-processing peptidase subunit alpha precursor & Collagen alpha-I (XII) chain \\
\hline Coiled-coil alpha-helical rod protein I & PREDICTED: SYF2 homolog, RNA splicing factor-like, partial \\
\hline Ankyrin repeat domain-containing protein 32 & Carboxypeptidase B2 precursor \\
\hline Complement $\mathrm{C} 5 \mathrm{a}$ anaphylatoxin & PREDICTED: titin \\
\hline von Willebrand factor & Seryl-tRNA synthetase, mitochondrial precursor \\
\hline PREDICTED: hemolytic complement-like & Probable phospholipid-transporting ATPase IA \\
\hline PREDICTED: ZARI-like protein-like & Coagulation factor XIII B chain \\
\hline Homeobox protein Hox-A4 & $26 \mathrm{~S}$ proteasome non-ATPase regulatory subunit I \\
\hline PREDICTED: recombination activating gene I & Filamin-C \\
\hline PREDICTED: FLJ00002 protein-like & Glycine $\mathrm{N}$-acyltransferase \\
\hline Heat-stable enterotoxin receptor & PREDICTED: hypothetical protein \\
\hline Reelin & PREDICTED: phospholipase D family, member 3-like \\
\hline Hypothetical protein LOCI00I24506 & von Willebrand factor $\mathrm{C}$ domain-containing protein 2-like \\
\hline Kelch repeat and BTB domain-containing protein 12 & Probable ATP-dependent RNA helicase DDX49 \\
\hline Tenascin C & PREDICTED: preferentially expressed antigen in melanoma-like \\
\hline Nucleoporin p58/p45 & Protein Shroom I \\
\hline
\end{tabular}


Table SI (Continued)

\begin{tabular}{|c|c|}
\hline DMEM-bare & DMEM-Si \\
\hline PREDICTED: transcriptional regulating factor I-like & Heat shock $70 \mathrm{kDa}$ protein IA \\
\hline Endoplasmin precursor & Hypothetical protein LOC6I4478 \\
\hline PREDICTED: chloride channel protein CIC-Ka-like & Insulin-like growth factor-binding protein complex acid labile subunit \\
\hline AP-I complex subunit mu-2 & PREDICTED: collagen, type VI, alpha 3-like isoform 4 \\
\hline TAF6-like RNA polymerase II p300/CBP associated factor & Actin-related protein 2 \\
\hline \multicolumn{2}{|l|}{65 kDa subunit 6L } \\
\hline \multicolumn{2}{|l|}{ Cyclin-G-associated kinase } \\
\hline \multicolumn{2}{|l|}{ ARF GTPase-activating protein GIT2 } \\
\hline \multicolumn{2}{|l|}{ Hexokinase-I } \\
\hline \multicolumn{2}{|l|}{ PREDICTED: histone cluster I, H2bd-like } \\
\hline \multicolumn{2}{|l|}{ Desmoplakin } \\
\hline \multicolumn{2}{|l|}{ Ras-related protein Rap-Ib precursor } \\
\hline \multicolumn{2}{|l|}{ PREDICTED: transforming growth factor, beta receptor III } \\
\hline \multicolumn{2}{|l|}{ Acetyl-CoA carboxylase I } \\
\hline \multicolumn{2}{|l|}{ PREDICTED: microtubule-associated protein 7-like } \\
\hline \multicolumn{2}{|l|}{ PREDICTED: centrosomal protein $110 \mathrm{kda}$} \\
\hline \multicolumn{2}{|l|}{ Serpin A3-7 } \\
\hline \multicolumn{2}{|l|}{ Voltage-dependent $\mathrm{N}$-type calcium channel subunit alpha-IB } \\
\hline \multicolumn{2}{|l|}{ Ribonucleoside-diphosphate reductase MI chain } \\
\hline \multicolumn{2}{|l|}{ Probable phospholipid-transporting ATPase IB } \\
\hline \multicolumn{2}{|l|}{ PREDICTED: hypothetical protein } \\
\hline \multicolumn{2}{|l|}{ Tubulin alpha-ID chain } \\
\hline \multicolumn{2}{|l|}{ Kinesin family member $\mathrm{C} 2$} \\
\hline \multicolumn{2}{|l|}{ Selenoprotein S } \\
\hline \multicolumn{2}{|l|}{ PREDICTED: mcg I 44546-like } \\
\hline \multicolumn{2}{|l|}{ Nucleoporin NUPI 88 homolog } \\
\hline \multicolumn{2}{|l|}{ Actin, cytoplasmic I } \\
\hline \multicolumn{2}{|l|}{ PREDICTED: centromere protein E, $312 \mathrm{kda}$} \\
\hline \multicolumn{2}{|l|}{ PREDICTED: zinc finger, DHHC-type containing I8-like } \\
\hline \multicolumn{2}{|l|}{ Butyrophilin-like protein I } \\
\hline PREDICTED: sodium channel protein type II subunit alpha-like & \\
\hline
\end{tabular}

Abbreviations: DMEM, Dulbecco's Modified Eagle's Medium; Si, silica; tRNA, transfer ribonucleic acid; ATP, adenosine triphosphate. 
Table S2 Protein corona list of RPMI-bare and RPMI-Si

\begin{tabular}{|c|c|}
\hline RPMI-bare & RPMI-Si \\
\hline PREDICTED: apolipoprotein B & PREDICTED: apolipoprotein B \\
\hline Fibronectin & Complement $\mathrm{c} 3$ preproprotein \\
\hline Complement $\mathrm{C} 3$ preproprotein & Alpha-2-macroglobulin \\
\hline Inter-alpha-trypsin inhibitor heavy chain $\mathrm{H} 2$ & Serum albumin precursor \\
\hline Alpha-2-macroglobulin & Inter-alpha-trypsin inhibitor heavy chain h2 \\
\hline Serum albumin precursor & Fibronectin \\
\hline Inter-alpha-trypsin inhibitor heavy chain $\mathrm{H} 3$ precursor & Inter-alpha-trypsin inhibitor heavy chain $\mathrm{H} 3$ precursor \\
\hline Thrombospondin-I precursor & Antithrombin-III precursor \\
\hline Inter-alpha-trypsin inhibitor heavy chain $\mathrm{HI}$ precursor & Apolipoprotein E precursor \\
\hline Gelsolin isoform a & Fibulin-I \\
\hline Talin-I & Inter-alpha-trypsin inhibitor heavy chain $\mathrm{HI}$ precursor \\
\hline Complement C4 & Complement C4 \\
\hline Fibulin-I & Periostin \\
\hline PREDICTED: pregnancy-zone protein-like & Talin- I \\
\hline Angiotensinogen & Predicted: pregnancy-zone protein-like \\
\hline Thrombospondin-4 precursor & Alpha-2-HS-glycoprotein precursor \\
\hline Antithrombin-III precursor & Apolipoprotein A-I preproprotein \\
\hline Heparin cofactor 2 & Heparin cofactor 2 \\
\hline Prothrombin & Gelsolin isoform a \\
\hline Vitronectin & Vitronectin \\
\hline Inter-alpha-trypsin inhibitor heavy chain $\mathrm{H} 4$ precursor & Angiotensinogen \\
\hline Periostin & Complement factor B precursor \\
\hline Alpha-2-HS-glycoprotein precursor & Serotransferrin precursor \\
\hline Alpha-I-antiproteinase precursor & Inter-alpha-trypsin inhibitor heavy chain $\mathrm{H} 4$ precursor \\
\hline Protein AMBP precursor & Alpha-I-antiproteinase precursor \\
\hline Hyaluronan-binding protein 2 & Hemoglobin fetal subunit beta \\
\hline Alpha-2-antiplasmin precursor & Prothrombin \\
\hline Coagulation factor $\mathrm{V}$ precursor & Hemoglobin subunit alpha \\
\hline Tubulin, beta I & Protein AMBP precursor \\
\hline Kininogen-2 isoform II & Fetuin-B precursor \\
\hline Tubulin beta- 5 chain & Tubulin, beta I \\
\hline PREDICTED: apolipoprotein B & Complement $\mathrm{C} 5 \mathrm{a}$ anaphylatoxin \\
\hline PREDICTED: collagen, type VI, alpha 3-like isoform 4 & Plasma serine protease inhibitor precursor \\
\hline Hemoglobin fetal subunit beta & Lipopolysaccharide-binding protein precursor \\
\hline Kininogen-2 isoform I & Kininogen-2 isoform II \\
\hline Apolipoprotein E precursor & Fermitin family homolog 3 \\
\hline Tubulin alpha-4A chain & Complement component $\mathrm{C} 9$ precursor \\
\hline Pigment epithelium-derived factor precursor & Actin, aortic smooth muscle \\
\hline Cartilage oligomeric matrix protein & Thrombospondin-I precursor \\
\hline Hypothetical protein LOC5I0860 & Alpha-2-antiplasmin precursor \\
\hline Heat shock protein HSP 90-beta & Hemoglobin subunit beta \\
\hline C4b-binding protein alpha chain precursor & Phospholipid transfer protein \\
\hline Mannan-binding lectin serine protease I & Complement component 8 , beta polypeptide \\
\hline Hemoglobin subunit beta & Fibrinogen beta chain \\
\hline Fibrinogen alpha chain precursor & Alpha-fetoprotein precursor \\
\hline Coagulation factor $X$ & Thrombospondin-4 precursor \\
\hline $\begin{array}{l}\text { PREDICTED: complement component } 4 \text { binding protein, } \\
\text { alpha chain-like }\end{array}$ & PREDICTED: apolipoprotein B \\
\hline Fibrinogen beta chain & Properdin \\
\hline Complement component $\mathrm{C} 9$ precursor & Hypothetical protein LOC510860 \\
\hline C-type lectin domain family II member A & C4b-binding protein alpha chain precursor \\
\hline Filamin-A & Coagulation factor $V$ precursor \\
\hline Fetuin-B precursor & PREDICTED: collagen, type VI, alpha 3-like isoform 4 \\
\hline Serpin A3-I precursor & Heat shock protein HSP 90-alpha \\
\hline Hemoglobin subunit alpha & $\begin{array}{l}\text { PREDICTED: complement component } 4 \text { binding protein, } \\
\text { alpha chain-like }\end{array}$ \\
\hline
\end{tabular}


Table S2 (Continued)

\begin{tabular}{|c|c|}
\hline RPMI-bare & RPMI-Si \\
\hline Alpha-fetoprotein precursor & Apolipoprotein A-II precursor \\
\hline PREDICTED: similar to complement component 4A & Coagulation factor $X$ \\
\hline Factor XIla inhibitor precursor & Elongation factor I-alpha 2 \\
\hline Neuropilin-2 & Pyruvate kinase isozymes $\mathrm{MI} / \mathrm{M} 2$ \\
\hline Fibrinogen gamma-B chain precursor & Kininogen-2 isoform I \\
\hline Nidogen-I & PREDICTED: similar to complement component 4A \\
\hline Collectin-II precursor & Heat shock protein HSP 90-beta \\
\hline Serpin A3-7 & Apolipoprotein M \\
\hline $\begin{array}{l}\text { PREDICTED: sushi, von Willebrand factor type A, EGF, and pentraxin domain } \\
\text { containing I, partial }\end{array}$ & PREDICTED: GLIS family zinc finger 3, partial \\
\hline Thyroglobulin precursor & Glyceraldehyde-3-phosphate dehydrogenase \\
\hline Lumican precursor & $\begin{array}{l}\text { PREDICTED: putative zinc finger protein ENSP00000330994- } \\
\text { like, partial }\end{array}$ \\
\hline Complement $\mathrm{C} 5 \mathrm{a}$ anaphylatoxin & Vitamin D-binding protein precursor \\
\hline Collagen alpha-I (XII) chain & Glyceraldehyde-3-phosphate dehydrogenase, testis-specific \\
\hline Vitamin D-binding protein precursor & Tubulin alpha-4A chain \\
\hline Fibromodulin & Hyaluronan-binding protein 2 \\
\hline Pentraxin-related protein PTX3 precursor & Actin, cytoplasmic I \\
\hline 6-Phosphogluconate dehydrogenase, decarboxylating & Adenosylhomocysteinase \\
\hline PREDICTED: GLIS family zinc finger 3, partial & Actin, alpha cardiac muscle I \\
\hline Neuropilin-I & PREDICTED: hCG I647286-like \\
\hline PREDICTED: heparan sulfate proteoglycan 2 & Transthyretin precursor \\
\hline Reelin & PREDICTED: calcineurin binding protein I \\
\hline Lipopolysaccharide-binding protein precursor & Carboxypeptidase b2 precursor \\
\hline CTAGE family, member 5 & Leucine-rich repeat-containing protein 49 \\
\hline Rab GDP dissociation inhibitor beta & Neural cell adhesion molecule I precursor \\
\hline PREDICTED: VGF nerve growth factor inducible-like & Biglycan precursor \\
\hline Actin, aortic smooth muscle & Tubulin alpha-ID chain \\
\hline Eukaroytic elongation factor 2 kinase & PREDICTED: phosphorylase kinase, beta \\
\hline Thrombospondin-3 & C-type lectin domain family II member A \\
\hline von Willebrand factor & Alpha-I-acid glycoprotein precursor \\
\hline SPARC-like protein I & Kelch-like ECH-associated protein I \\
\hline Alpha-actinin-I & Coagulation factor XIII A chain precursor \\
\hline Apolipoprotein A-I preproprotein & PREDICTED: cadherin 4, type I preproprotein-like \\
\hline Carbohydrate sulfotransferase 3 & PREDICTED: neurofilament, medium polypeptide \\
\hline Serine/threonine-protein phosphatase 2A 65 kda & ATP synthase subunit $D$, mitochondrial \\
\hline \multicolumn{2}{|l|}{ regulatory subunit $A$ alpha isoform } \\
\hline Actin, cytoplasmic I & PREDICTED: mcg | 44546-like \\
\hline tRNA-dihydrouridine synthase I-like & Neutrophil cytosol factor I \\
\hline Retinoic acid receptor responder (tazarotene induced) I & Alpha-SI-casein precursor \\
\hline Interleukin-I beta precursor & Serpin A3-I precursor \\
\hline NACHT, LRR, and PYD domains-containing protein 5 & 6-Phosphogluconate dehydrogenase, decarboxylating \\
\hline Hypothetical protein LOC78I988 & Pigment epithelium-derived factor precursor \\
\hline Tenascin- $\mathrm{X}$ & Serpin A3-7 \\
\hline Heat shock protein HSP 90-alpha & PREDICTED: collagen, type IV, alpha 2, partial \\
\hline Mannan-binding lectin serine protease 2 & Tyrosine-protein kinase BAZIB \\
\hline Galectin-3-binding protein precursor & Inner nuclear membrane protein MANI \\
\hline Adenosine deaminase-like protein & PREDICTED: NIMA (never in mitosis gene a)-related kinase II \\
\hline Ankyrin repeat domain-containing protein 32 & Nucleolar GTP-binding protein 2 \\
\hline PREDICTED: hCG I 647286-like & Annexin A2 \\
\hline Fatty acid synthase & SPARC-like protein I \\
\hline Tenascin C & L-lactate dehydrogenase $C$ isoform I \\
\hline Apolipoprotein M & Casein kinase II subunit alpha \\
\hline Ras-related protein Rap-Ib precursor & Glycine N-acyltransferase \\
\hline Zinc finger protein 366 & Fibrinogen alpha chain precursor \\
\hline PREDICTED: multiple C2 domains, transmembrane I-like & Peroxisomal biogenesis factor 3 \\
\hline
\end{tabular}


Table S2 (Continued)

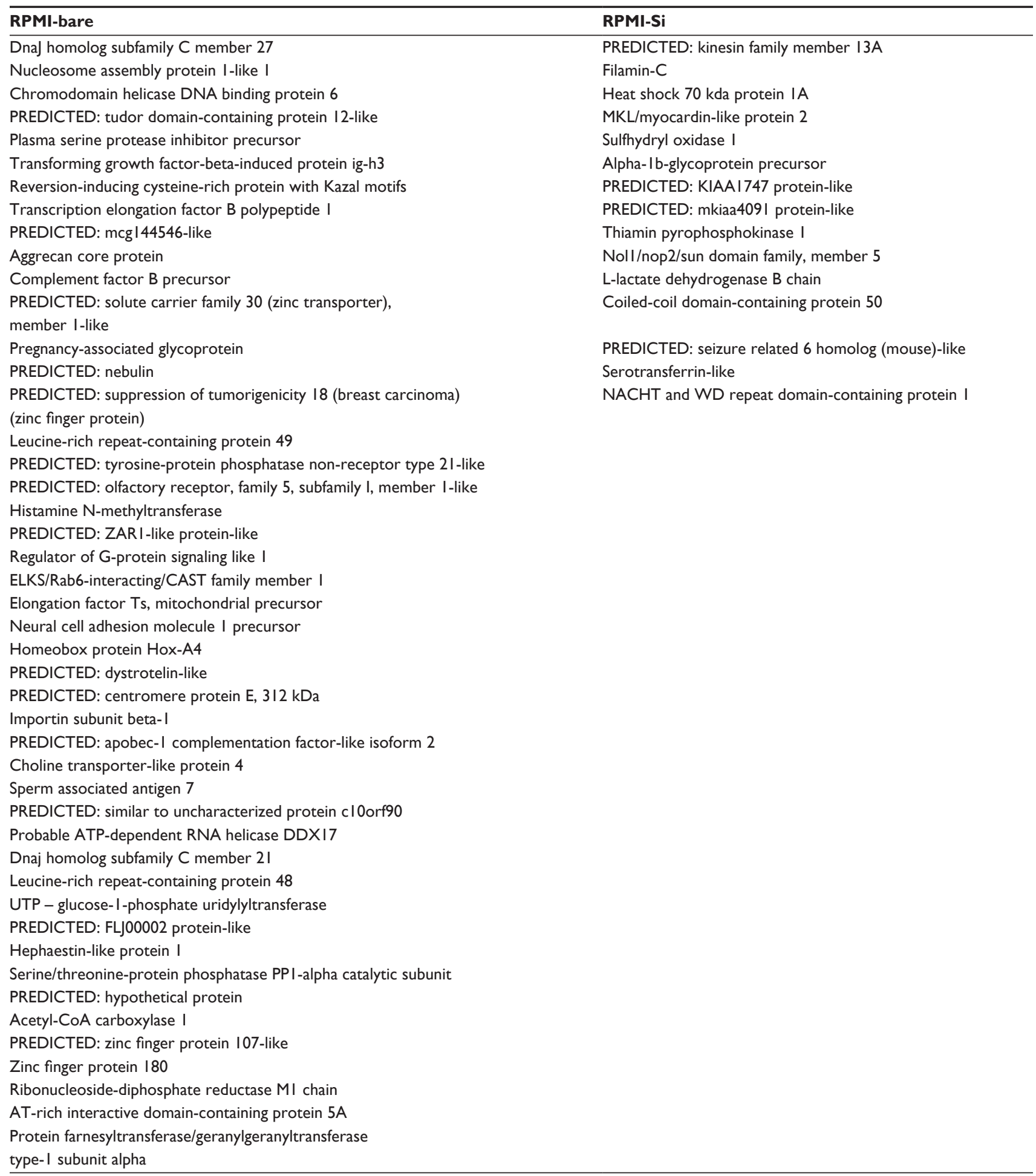

Abbreviations: Si, silica; ATP, adenosine triphosphate; tRNA, transfer ribonucleic acid; RPMI, Roswell Park Memorial Institute. 
Table S3 List of DMEM common proteins involved in both AuNRs and $\mathrm{SiO}_{2}$-AuNRs

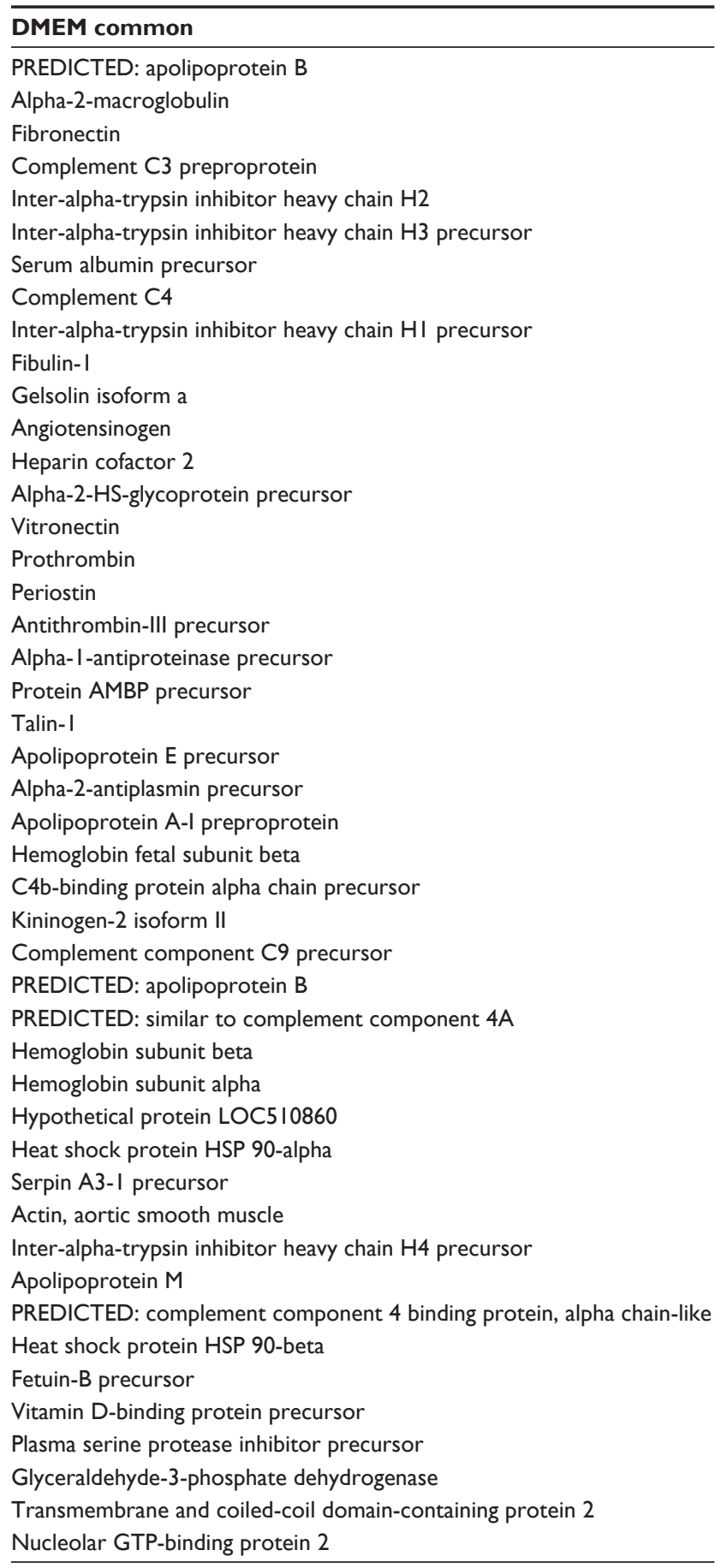

Abbreviations: DMEM, Dulbecco's Modified Eagle's Medium; AuNRs, gold nanorods; $\mathrm{SiO}_{2}$-AuNRs, gold nanorods functionalized with silica.
Table S4 List of RPMI common proteins involved in both AuNRs and $\mathrm{SiO}_{2}$-AuNRs

\section{RPMI common}

PREDICTED: apolipoprotein B

Fibronectin

Complement C3 preproprotein

Inter-alpha-trypsin inhibitor heavy chain $\mathrm{H} 2$

Alpha-2-macroglobulin

Serum albumin precursor

Inter-alpha-trypsin inhibitor heavy chain $\mathrm{H} 3$ precursor

Thrombospondin-I precursor

Inter-alpha-trypsin inhibitor heavy chain $\mathrm{HI}$ precursor

Gelsolin isoform a

Talin-I

Complement C4

Fibulin-I

PREDICTED: pregnancy-zone protein-like

Angiotensinogen

Thrombospondin-4 precursor

Antithrombin-III precursor

Heparin cofactor 2

Prothrombin

Vitronectin

Inter-alpha-trypsin inhibitor heavy chain $\mathrm{H} 4$ precursor

Periostin

Alpha-2-HS-glycoprotein precursor

Alpha-I-antiproteinase precursor

Protein AMBP precursor

Hyaluronan-binding protein 2

Alpha-2-antiplasmin precursor

Coagulation factor $\mathrm{V}$ precursor

Tubulin, beta I

Kininogen-2 isoform II

PREDICTED: apolipoprotein B

PREDICTED: collagen, type VI, alpha 3-like isoform 4

Hemoglobin fetal subunit beta

Kininogen-2 isoform I

Apolipoprotein E precursor

Tubulin alpha-4A chain

Hypothetical protein LOC5I0860

Heat shock protein HSP 90-beta

C4b-binding protein alpha chain precursor

Hemoglobin subunit beta

Coagulation factor $X$

PREDICTED: complement component 4 binding protein, alpha chain-like

Fibrinogen beta chain

Complement component $\mathrm{C} 9$ precursor

C-type lectin domain family II member A

Fetuin-B precursor

Hemoglobin subunit alpha

Alpha-fetoprotein precursor

PREDICTED: similar to complement component 4A

Complement $\mathrm{C} 5 \mathrm{a}$ anaphylatoxin

Vitamin D-binding protein precursor

PREDICTED: GLIS family zinc finger 3, partial

Lipopolysaccharide-binding protein precursor

Actin, aortic smooth muscle

Apolipoprotein A-I preproprotein

Actin, cytoplasmic I

Heat shock protein HSP 90-alpha

PREDICTED: hCGI647286-like

Apolipoprotein M

Abbreviations: AuNRs, gold nanorods; $\mathrm{SiO}_{2}$-AuNRs, gold nanorods functionalized with silica; RPMI, Roswell Park Memorial Institute. 
Table S5 List of DMEM unique proteins involved in either AuNRs or $\mathrm{SiO}_{2}-\mathrm{AuNRs}$

DMEM uncommon

PREDICTED: pregnancy-zone protein-like

Thrombospondin-I precursor

Thrombospondin-4 precursor

Thyroglobulin precursor

Coagulation factor $\vee$ precursor

Hyaluronan-binding protein 2

Tubulin, beta I

PREDICTED: heparan sulfate proteoglycan 2

Fibrinogen alpha chain precursor

Factor XIla inhibitor precursor

Tubulin alpha-4A chain

Kininogen-2 isoform I

Mannan-binding lectin serine protease I

Fibrinogen beta chain

Tenascin-X

Collagen alpha-I (XII) chain

Tubulin beta-5 chain

Fibromodulin

Lumican precursor

Alpha-actinin- I

Neuropilin- I

Echinoderm microtubule-associated protein-like 5

PREDICTED: alpha-2-macroglobulin-like, partial

Aggrecan core protein

PREDICTED: GLIS family zinc finger 3, partial

PREDICTED: calcium channel, voltage-dependent, $L$ type,

alpha IS subunit-like

Myosin, heavy chain 9, nonmuscle

Caspase-14

tRNA-dihydrouridine synthase I-like

Myosin- I I

PREDICTED: KRAB-A domain containing 2

Thrombospondin-3

Neuropilin-2

Beta-casein precursor

PREDICTED: collagen, type VI, alpha 3-like isoform 4

Sucrase-isomaltase, intestinal

Complement factor B precursor

Interleukin-I beta precursor

PREDICTED: NIMA (never in mitosis gene a)-related kinase I I

Coagulation factor $X$

SPARC-like protein I

PREDICTED: FYVE and coiled-coil domain-containing protein I-like

PREDICTED: thiolester containing protein II-like

Carbohydrate sulfotransferase 3

PREDICTED: zinc finger protein 347-like

C-type lectin domain family II member A

Terminal uridylyltransferase 4

Alpha-SI-casein precursor

Collectin-II precursor

Mannan-binding lectin serine protease 2

$\mathrm{N}$-acetylated-alpha-linked acidic dipeptidase 2

Pentraxin-related protein PTX3 precursor

6-phosphogluconate dehydrogenase, decarboxylating

Nidogen-I

Mitochondrial-processing peptidase subunit alpha precursor

Coiled-coil alpha-helical rod protein I

\section{DMEM-Si}

Lipopolysaccharide-binding protein precursor

Coagulation factor XIII A chain precursor

Serotransferrin precursor

Phosphoglycerate kinase I

Actin, cytoplasmic I

L-lactate dehydrogenase $B$ chain

Apolipoprotein A-II precursor

Fermitin family homolog 3

Phospholipid transfer protein

Pyruvate kinase isozymes MI/M2

Adenosylhomocysteinase

Complement component 8, beta polypeptide

Kelch-like $\mathrm{ECH}$-associated protein I

Alpha-enolase

Glyceraldehyde-3-phosphate dehydrogenase, testis-specific

Probable arginyl-tRNA synthetase, mitochondrial precursor

L-lactate dehydrogenase $\mathrm{C}$ isoform I

Thyroxine-binding globulin precursor

Neutrophil cytosol factor I

Apolipoprotein $\mathrm{D}$ precursor

Abbreviations: DMEM, Dulbecco's Modified Eagle's Medium; AuNRs, gold nanorods; $\mathrm{SiO}_{2}$-AuNRs, gold nanorods functionalized with silica; tRNA, transfer ribonucleic acid. 
Table S6 List of RPMI unique proteins involved in either AuNRs or $\mathrm{SiO}_{2}$-AuNRs

\begin{tabular}{|c|c|}
\hline \multicolumn{2}{|l|}{ RPMI uncommon } \\
\hline RPMI-bare & RPMI-Si \\
\hline Tubulin beta- 5 chain & Complement factor B precursor \\
\hline Pigment epithelium-derived factor precursor & Serotransferrin precursor \\
\hline Cartilage oligomeric matrix protein & Plasma serine protease inhibitor precursor \\
\hline Mannan-binding lectin serine protease I & Fermitin family homolog 3 \\
\hline Fibrinogen alpha chain precursor & Phospholipid transfer protein \\
\hline Filamin-A & Complement component 8 , beta polypeptide \\
\hline Serpin A3-I precursor & Properdin \\
\hline Factor Xlla inhibitor precursor & Apolipoprotein A-II precursor \\
\hline Neuropilin-2 & Elongation factor I-alpha 2 \\
\hline Fibrinogen gamma-B chain precursor & Pyruvate kinase isozymes MI/M2 \\
\hline Nidogen-I & Glyceraldehyde-3-phosphate dehydrogenase \\
\hline \multirow[t]{2}{*}{ Collectin-II precursor } & PREDICTED: Putative zinc finger protein \\
\hline & ENSP00000330994-like, partial \\
\hline Serpin A3-7 & Glyceraldehyde-3-phosphate dehydrogenase, testis-specific \\
\hline $\begin{array}{l}\text { PREDICTED: sushi, von Willebrand factor type A, EGF, } \\
\text { and pentraxin domain containing I, partial }\end{array}$ & Adenosylhomocysteinase \\
\hline Thyroglobulin precursor & Actin, alpha cardiac muscle I \\
\hline Lumican precursor & Transthyretin precursor \\
\hline Collagen alpha-I (XII) chain & PREDICTED: calcineurin binding protein I \\
\hline Fibromodulin & Carboxypeptidase B2 precursor \\
\hline Pentraxin-related protein PTX3 precursor & Leucine-rich repeat-containing protein 49 \\
\hline 6-phosphogluconate dehydrogenase, decarboxylating & Neural cell adhesion molecule I precursor \\
\hline Neuropilin-I & Biglycan precursor \\
\hline PREDICTED: heparan sulfate proteoglycan 2 & Tubulin alpha-ID chain \\
\hline Reelin & PREDICTED: phosphorylase kinase, beta \\
\hline CTAGE family, member 5 & Alpha-I-acid glycoprotein precursor \\
\hline Rab GDP dissociation inhibitor beta & Kelch-like ECH-associated protein I \\
\hline \multicolumn{2}{|l|}{ PREDICTED: VGF nerve growth factor inducible-like } \\
\hline \multicolumn{2}{|l|}{ Eukaroytic elongation factor 2 kinase } \\
\hline \multicolumn{2}{|l|}{ Thrombospondin-3 } \\
\hline \multicolumn{2}{|l|}{ von Willebrand factor } \\
\hline \multicolumn{2}{|l|}{ SPARC-like protein I } \\
\hline \multicolumn{2}{|l|}{ Alpha-actinin-I } \\
\hline \multicolumn{2}{|l|}{ Carbohydrate sulfotransferase 3} \\
\hline \multicolumn{2}{|l|}{ Serine/threonine-protein phosphatase $2 \mathrm{~A} 65 \mathrm{kDa}$ regulatory } \\
\hline \multicolumn{2}{|l|}{ subunit $A$ alpha isoform } \\
\hline \multicolumn{2}{|l|}{ tRNA-dihydrouridine synthase I-like } \\
\hline \multicolumn{2}{|l|}{ Retinoic acid receptor responder (tazarotene induced) I } \\
\hline \multicolumn{2}{|l|}{ Interleukin-I beta precursor } \\
\hline \multicolumn{2}{|l|}{ NACHT, LRR, and PYD domains-containing protein 5} \\
\hline \multicolumn{2}{|l|}{ Hypothetical protein LOC78I988 } \\
\hline \multicolumn{2}{|l|}{ Tenascin- $X$} \\
\hline \multicolumn{2}{|l|}{ Mannan-binding lectin serine protease 2} \\
\hline \multicolumn{2}{|l|}{ Galectin-3-binding protein precursor } \\
\hline \multicolumn{2}{|l|}{ Adenosine deaminase-like protein } \\
\hline \multicolumn{2}{|l|}{ Ankyrin repeat domain-containing protein 32} \\
\hline \multicolumn{2}{|l|}{ Fatty acid synthase } \\
\hline Tenascin C & \\
\hline Ras-related protein Rap-Ib precursor & \\
\hline Zinc finger protein 366 & \\
\hline
\end{tabular}

Abbreviations: AuNRs, gold nanorods; $\mathrm{SiO}_{2}$-AuNRs, gold nanorods functionalized with silica; $\mathrm{Si}$, silica; tRNA, transfer ribonucleic acid; RPMl, Roswell Park Memorial Institute. 
Table S7 List of AuNRs attached common proteins involved in both DMEM and RPMI

\begin{tabular}{|c|}
\hline BARE common \\
\hline PREDICTED: apolipoprotein B \\
\hline Alpha-2-macroglobulin \\
\hline Fibronectin \\
\hline Complement C3 preproprotein \\
\hline Inter-alpha-trypsin inhibitor heavy chain $\mathrm{H} 2$ \\
\hline Inter-alpha-trypsin inhibitor heavy chain $\mathrm{H} 3$ precursor \\
\hline Serum albumin precursor \\
\hline Complement C4 \\
\hline Inter-alpha-trypsin inhibitor heavy chain $\mathrm{HI}$ precursor \\
\hline Fibulin-I \\
\hline PREDICTED: pregnancy-zone protein-like \\
\hline Gelsolin isoform a \\
\hline Thrombospondin-I precursor \\
\hline Angiotensinogen \\
\hline Heparin cofactor 2 \\
\hline Alpha-2-HS-glycoprotein precursor \\
\hline Vitronectin \\
\hline Prothrombin \\
\hline Periostin \\
\hline Thrombospondin-4 precursor \\
\hline Antithrombin-III precursor \\
\hline Alpha-I-antiproteinase precursor \\
\hline Protein AMBP precursor \\
\hline Talin-I \\
\hline Thyroglobulin precursor \\
\hline Apolipoprotein E precursor \\
\hline Alpha-2-antiplasmin precursor \\
\hline Apolipoprotein A-I preproprotein \\
\hline Hemoglobin fetal subunit beta \\
\hline Coagulation factor $V$ precursor \\
\hline Hyaluronan-binding protein 2 \\
\hline C4b-binding protein alpha chain precursor \\
\hline Kininogen-2 isoform II \\
\hline Complement component $\mathrm{C} 9$ precursor \\
\hline PREDICTED: apolipoprotein B \\
\hline Tubulin, beta I \\
\hline PREDICTED: similar to complement component 4A \\
\hline PREDICTED: heparan sulfate proteoglycan 2 \\
\hline Hemoglobin subunit beta \\
\hline Fibrinogen alpha chain precursor \\
\hline Hemoglobin subunit alpha \\
\hline Hypothetical protein LOC5I 0860 \\
\hline
\end{tabular}

Table S7 (Continued)

\section{BARE common}

Heat shock protein HSP 90-alpha

Serpin A3-I precursor

Factor Xlla inhibitor precursor

Actin, aortic smooth muscle

Tubulin alpha-4A chain

Kininogen-2 isoform I

Inter-alpha-trypsin inhibitor heavy chain $\mathrm{H} 4$ precursor

Mannan-binding lectin serine protease I

Apolipoprotein M

Fibrinogen beta chain

Tenascin-X

PREDICTED: complement component 4 binding protein, alpha chain-like Collagen alpha-I (XII) chain

Heat shock protein HSP 90-beta

Tubulin beta- 5 chain

Fibromodulin

Fetuin-B precursor

Lumican precursor

Alpha-actinin-I

Vitamin D-binding protein precursor

Neuropilin-I

PREDICTED: GLIS family zinc finger 3, partial

tRNA-dihydrouridine synthase I-like

Thrombospondin-3

Neuropilin-2

PREDICTED: collagen, type VI, alpha 3-like isoform 4

Interleukin-I beta precursor

Coagulation factor $X$

SPARC-like protein I

Carbohydrate sulfotransferase 3

C-type lectin domain family II member A

Collectin-I I precursor

Mannan-binding lectin serine protease 2

Pentraxin-related protein PTX3 precursor

6-phosphogluconate dehydrogenase, decarboxylating

Nidogen-1

Abbreviations: AuNRs, gold nanorods; DMEM, Dulbecco's Modified Eagle's Medium; tRNA, transfer ribonucleic acid; RPMI, Roswell Park Memorial Institute. 
Table S8 $\mathrm{List}$ of $\mathrm{SiO}_{2}$-AuNRs attached common proteins involved in both DMEM and RPMI

\begin{tabular}{l} 
Si common \\
\hline PREDICTED: apolipoprotein B \\
Complement C3 preproprotein \\
Serum albumin precursor \\
Alpha-2-macroglobulin \\
Antithrombin-III precursor \\
Apolipoprotein E precursor \\
Inter-alpha-trypsin inhibitor heavy chain $\mathrm{H} 2$ \\
Apolipoprotein A-I preproprotein \\
Fibulin-I \\
Alpha-I-antiproteinase precursor \\
Alpha-2-HS-glycoprotein precursor \\
Complement C4 \\
Periostin \\
Inter-alpha-trypsin inhibitor heavy chain H3 precursor \\
Hemoglobin subunit alpha \\
Vitronectin \\
Heparin cofactor 2 \\
Prothrombin \\
Inter-alpha-trypsin inhibitor heavy chain H4 precursor \\
Hemoglobin fetal subunit beta \\
Angiotensinogen \\
PREDICTED: complement component 4 binding protein, alpha chain-like \\
Gelsolin isoform a \\
Protein AMBP precursor \\
Fetuin-B precursor \\
Lipopolysaccharide-binding protein precursor \\
Plasma serine protease inhibitor precursor \\
Complement component C9 precursor \\
Actin, aortic smooth muscle \\
\hline
\end{tabular}

Table S8 (Continued)

\begin{tabular}{l}
\hline Si common \\
\hline Talin-I \\
PREDICTED: apolipoprotein B \\
Serotransferrin precursor \\
Hemoglobin subunit beta \\
Alpha-2-antiplasmin precursor \\
Inter-alpha-trypsin inhibitor heavy chain HI precursor \\
Actin, cytoplasmic I \\
Apolipoprotein A-II precursor \\
Fibronectin \\
Hypothetical protein LOC5I0860 \\
Heat shock protein HSP 90 -beta \\
Fermitin family homolog 3 \\
Phospholipid transfer protein \\
Pyruvate kinase isozymes MI/M2 \\
Adenosylhomocysteinase \\
Complement component 8 , beta polypeptide \\
Kininogen-2 isoform II \\
Kelch-like ECH-associated protein I \\
Apolipoprotein M \\
Glyceraldehyde-3-phosphate dehydrogenase \\
Glyceraldehyde-3-phosphate dehydrogenase, testis-specific \\
Vitamin D-binding protein precursor \\
Heat shock protein HSP 90 -alpha \\
C4b-binding protein alpha chain precursor \\
\hline Ab
\end{tabular}

Abbreviations: $\mathrm{SiO}_{2}$-AuNRs, gold nanorods functionalized with silica; $\mathrm{Si}$, silica; DMEM, Dulbecco's Modified Eagle's Medium; RPMI, Roswell Park Memorial Institute. 
Table S9 List of AuNRs attached unique proteins involved in either DMEM or RPMI

\begin{tabular}{|c|c|}
\hline \multicolumn{2}{|l|}{ Bare uncommon } \\
\hline DMEM-bare & RPMI-bare \\
\hline Echinoderm microtubule-associated protein-like 5 & Pigment epithelium-derived factor precursor \\
\hline PREDICTED: alpha-2-macroglobulin-like, partial & Cartilage oligomeric matrix protein \\
\hline Aggrecan core protein & Filamin-A \\
\hline Plasma serine protease inhibitor precursor & Alpha-fetoprotein precursor \\
\hline $\begin{array}{l}\text { PREDICTED: calcium channel, voltage-dependent, } L \text { type, } \\
\text { alpha IS subunit-like }\end{array}$ & Fibrinogen gamma-B chain precursor \\
\hline Myosin, heavy chain 9 , nonmuscle & Serpin A3-7 \\
\hline Glyceraldehyde-3-phosphate dehydrogenase & $\begin{array}{l}\text { PREDICTED: sushi, von Willebrand factor type A, EGF, } \\
\text { and pentraxin domain containing I, partial }\end{array}$ \\
\hline Caspase-14 & Complement $\mathrm{C} 5 \mathrm{a}$ anaphylatoxin \\
\hline Myosin-II & Reelin \\
\hline PREDICTED: KRAB-A domain containing 2 & Lipopolysaccharide-binding protein precursor \\
\hline Beta-casein precursor & CTAGE family, member 5 \\
\hline Sucrase-isomaltase, intestinal & Rab GDP dissociation inhibitor beta \\
\hline Transmembrane and coiled-coil domain-containing protein 2 & PREDICTED: VGF nerve growth factor inducible-like \\
\hline Complement factor B precursor & Eukaroytic elongation factor 2 kinase \\
\hline PREDICTED: NIMA (never in mitosis gene a)-related kinase II & von Willebrand factor \\
\hline PREDICTED: FYVE and coiled-coil domain-containing & Serine/threonine-protein phosphatase $2 \mathrm{~A} 65 \mathrm{kDa}$ regulatory \\
\hline protein I-like & subunit $A$ alpha isoform \\
\hline PREDICTED: thiolester containing protein II-like & Actin, cytoplasmic I \\
\hline PREDICTED: zinc finger protein 347-like & Retinoic acid receptor responder (tazarotene induced) I \\
\hline Terminal uridylyltransferase 4 & NACHT, LRR, and PYD domains-containing protein 5 \\
\hline Nucleolar GTP-binding protein 2 & Hypothetical protein LOC781988 \\
\hline Alpha-SI-casein precursor & Galectin-3-binding protein precursor \\
\hline $\mathrm{N}$-acetylated-alpha-linked acidic dipeptidase 2 & Adenosine deaminase-like protein \\
\hline Mitochondrial-processing peptidase subunit alpha precursor & Ankyrin repeat domain-containing protein 32 \\
\hline \multirow[t]{5}{*}{ Coiled-coil alpha-helical rod protein I } & PREDICTED: hCG I647286-like \\
\hline & Fatty acid synthase \\
\hline & Tenascin C \\
\hline & Ras-related protein Rap-Ib precursor \\
\hline & Zinc finger protein 366 \\
\hline
\end{tabular}

Abbreviations: AuNRs, gold nanorods; DMEM, Dulbecco's Modified Eagle's Medium; RPMI, Roswell Park Memorial Institute. 
Table SIO List of $\mathrm{SiO}_{2}$-AuNRs attached unique proteins involved in either DMEM or RPMI

\begin{tabular}{|c|c|}
\hline \multicolumn{2}{|l|}{ Si uncommon } \\
\hline DMEM-Si & RPMI-Si \\
\hline Coagulation factor XIII A chain precursor & PREDICTED: pregnancy-zone protein-like \\
\hline Phosphoglycerate kinase I & Complement factor B precursor \\
\hline L-lactate dehydrogenase $B$ chain & Tubulin, beta I \\
\hline Alpha-enolase & Complement $\mathrm{C} 5 \mathrm{a}$ anaphylatoxin \\
\hline Transmembrane and coiled-coil domain-containing protein 2 & Thrombospondin-I precursor \\
\hline Probable arginyl-tRNA synthetase, mitochondrial precursor & Fibrinogen beta chain \\
\hline Serpin A3-I precursor & Alpha-fetoprotein precursor \\
\hline L-lactate dehydrogenase $\mathrm{C}$ isoform I & Thrombospondin-4 precursor \\
\hline Nucleolar GTP-binding protein 2 & Properdin \\
\hline Thyroxine-binding globulin precursor & Coagulation factor $\mathrm{V}$ precursor \\
\hline Neutrophil cytosol factor I & PREDICTED: collagen, type $\mathrm{VI}$, alpha 3 -like isoform 4 \\
\hline \multirow[t]{20}{*}{ Apolipoprotein D precursor } & Coagulation factor $X$ \\
\hline & Elongation factor I-alpha 2 \\
\hline & Kininogen-2 isoform I \\
\hline & PREDICTED: GLIS family zinc finger 3, partial \\
\hline & PREDICTED: Putative zinc finger protein \\
\hline & ENSP00000330994-like, partial \\
\hline & Tubulin alpha-4A chain \\
\hline & Hyaluronan-binding protein 2 \\
\hline & Actin, alpha cardiac muscle I \\
\hline & PREDICTED: hCG I647286-like \\
\hline & Transthyretin precursor \\
\hline & PREDICTED: calcineurin binding protein I \\
\hline & Carboxypeptidase B2 precursor \\
\hline & Leucine-rich repeat-containing protein 49 \\
\hline & Neural cell adhesion molecule I precursor \\
\hline & Biglycan precursor \\
\hline & Tubulin alpha-ID chain \\
\hline & PREDICTED: phosphorylase kinase, beta \\
\hline & C-type lectin domain family II member A \\
\hline & Alpha-I-acid glycoprotein precursor \\
\hline
\end{tabular}

Abbreviations: $\mathrm{SiO}_{2}$-AuNRs, gold nanorods functionalized with silica; DMEM, Dulbecco's Modified Eagle's Medium; Si, silica; tRNA, transfer ribonucleic acid; RPMI, Roswell Park Memorial Institute.

\section{Publish your work in this journal}

The International Journal of Nanomedicine is an international, peerreviewed journal focusing on the application of nanotechnology in diagnostics, therapeutics, and drug delivery systems throughout the biomedical field. This journal is indexed on PubMed Central, MedLine, CAS, SciSearch $®$, Current Contents $\AA /$ Clinical Medicine,
Journal Citation Reports/Science Edition, EMBase, Scopus and the Elsevier Bibliographic databases. The manuscript management system is completely online and includes a very quick and fair peer-review system, which is all easy to use. Visit http://www.dovepress.com/ testimonials.php to read real quotes from published authors.

\footnotetext{
Submit your manuscript here: http://www.dovepress.com/international-journal-of-nanomedicine-journal
} 